Finance and Economics Discussion Series Divisions of Research \& Statistics and Monetary Affairs Federal Reserve Board, Washington, D.C.

Bank Core Deposits and the Mitigation of Monetary Policy

Lamont Black, Diana Hancock, and Wayne Passmore

2007-65

NOTE: Staff working papers in the Finance and Economics Discussion Series (FEDS) are preliminary materials circulated to stimulate discussion and critical comment. The analysis and conclusions set forth are those of the authors and do not indicate concurrence by other members of the research staff or the Board of Governors. References in publications to the Finance and Economics Discussion Series (other than acknowledgement) should be cleared with the author(s) to protect the tentative character of these papers. 


\title{
Bank Core Deposits And the Mitigation of Monetary Policy ${ }^{\Upsilon}$
}

\author{
Lamont Black, Diana Hancock and Wayne Passmore \\ Board of Governors of the Federal Reserve System \\ Washington, DC 20551
}

\begin{abstract}
We consider the business strategy of some banks that provide relationship loans (where they have loan origination and monitoring advantages relative to capital markets) with core deposit funding (where they can pass along the benefit of a sticky price on deposits). These "traditional banks" tend to lend out less than the deposits they take in, so they have a "buffer stock" of core deposits. This buffer stock of core deposits can be used to mitigate the full effect of tighter monetary policy on their bank-dependent borrowers. In this manner, the business strategy of "traditional banks" acts as a "core deposit mitigation channel" to provide funds to bankdependent borrowers when there are monetary shocks. In effect, there is no bank lending channel of monetary policy associated with these traditional banks.

In contrast, other banks mainly rely on managed liabilities that are priced at market rates. These banks do not have to shift from insured deposits to managed liabilities in response to tighter monetary policy. At the margin, their loans are already funded with managed liabilities. For these banks as well, there is no unique bank lending channel of monetary policy.

The only banks that are likely to raise loan rates substantially in response to an increase in the federal funds rate are banks with a high proportion of relationship loans that are close to a loanto-core deposit ratio of one. These banks must substitute higher cost nondeposit liabilities, which have an external finance premium, for core deposits, which do not because of deposit insurance. Some of these banks may also face higher marginal costs as their loan-to-core deposit ratio approaches one because of the costs associated with lending to default-prone relationship borrowers. It is among these banks (which we refer to as high relationship lenders), and only these banks, that we find evidence of a bank lending channel - they significantly reduce lending in response to a monetary contraction. Importantly, these banks hold only a small fraction of U.S. banking assets. Thus, in the United States, the bank lending channel seems limited in scope and importance, mainly because so few banks that specialize in relationship lending switch from core deposits to managed liabilities in response to changes in interest rates.
\end{abstract}

\footnotetext{
${ }^{\Upsilon}$ The views expressed are those of the authors and do not necessarily reflect those of the Board of Governors of the Federal Reserve System or its staff. The authors wish to thank Jerry Dwyer and participants at the conference on "The Credit Channel of Monetary Policy in the $21^{\text {st }}$ Century" (held at the Federal Reserve Bank of Atlanta on June 14, 2007) for their useful comments. The authors thank Reid Dorsey-Palmateer and Jessica Lee for their outstanding research assistance. All errors remain those of the authors.
} 


\section{INTRODUCTION}

There is considerable interest in whether monetary policy can influence the supply of intermediated credit, particularly the loans made by commercial banks to bankdependent borrowers (e.g., small and medium-sized businesses) who may not be able to obtain credit elsewhere. Much of the discussion of the "bank lending channel" has focused on whether monetary policy can significantly affect the relative pricing of bank loans by reducing bank’s access to loanable funds (e.g., Bernanke and Gertler, 1995). This effect of monetary policy, transmitted through the level and composition of bank assets, would be in addition to the traditional money supply and interest-rate effects, which may also be reflected in declining bank liabilities.

The transmission mechanism for the bank lending channel is easily explained, but has proved difficult to empirically detect. During a monetary tightening, open-market sales by the Fed would likely shrink banks' core deposit base and force these depositories to rely more heavily on managed liabilities. As these depositories shift their liabilities toward managed liabilities, the relative cost of their funds increases.

The shift by banks from insured retail deposits to nondeposit (or managed) liabilities creates an external finance premium for banks, similar to the external finance premium of firms that underlies financial accelerator models. The people and institutions that lend money to banks without the backing of the government (nondeposit liabilities) charge banks a credit premium based on the bank's credit quality. Banks respond by raising loan rates, which increases the cost of financing for bank-dependent borrowers, and possibly reduces the supply of loans to such borrowers.

Although the data on interest rate spreads (for banks' cost of funds and for the prime loans offered by banks), as well as on the terms of small business lending, are consistent with the bank lending channel mechanism, such data are also consistent with a tightening of monetary policy that worsens both borrowers' and banks' balance sheets. Such balance sheet effects alone could conceivably explain why it is observed that borrowing becomes more expensive (i.e., there are higher spreads) and more difficult (i.e., there are tougher terms for bank lending) during periods of tighter monetary policy. Thus, the identification of a "pure" bank lending channel where the contraction of loans 
reflects rising funding costs for banks, and not borrower balance sheet deterioration, has been difficult.

Because it has been difficult to detect the bank lending channel using aggregate data, some researchers have considered how monetary policy differentially impacts the lending behavior of a cross-section of individual banks. For example, Kashyap and Stein (1995 and 2000), have argued that small banks have the most costly access to external funds, and that among small banks, those with less liquid portfolios (i.e., those with a smaller buffer stock of securities) would be most likely to raise their loan rates. If these banks increase their rates more than other banks when monetary policy causes interest rates to increase, then their contraction in loans should be more pronounced than the contraction in loans at other banks. Empirically, one should observe smaller banks with less access to wholesale sources of funds and with smaller securities portfolios to have a greater response to monetary contractions. (This identification strategy assumes that there is little correlation between the securities holdings of small banks and the propensity of their borrowers to contract their demand for loans.)

The empirical evidence during the 1980's and early 1990's is consistent with this view, with tighter monetary policy resulting in a larger contraction in lending at smaller banks with the least liquid balance sheets. Not surprisingly, for the largest banks, the liquidity of the balance sheet is less important because such banks have an easier time accessing managed liability markets.

However, during the past decade, the liquidity at small banks has noticeably improved. Smaller institutions have a much wider variety of low-cost alternatives to deposits, such as Federal Home Loan Banks advances and brokered insured CDs. Furthermore, securitization opportunities are available to all banks now, including the smallest. Finally as we suggest here, some banks may be aware that their borrowers are more sensitive to increases in the loan rate, and thus might seek to adjust their balance sheets to immunize their bank-dependent borrowers from interest rate changes. Consequently, we propose a different approach to identification of the bank lending channel.

In this paper, we consider the business strategy of some banks that provide relationship loans (where they have loan origination and monitoring advantages relative 
to capital markets) with core deposit funding (where they can pass along the benefit of a sticky price on deposits). These "traditional banks" tend to lend out less than the deposits they take in, so they have a "buffer stock" of core deposits. This buffer stock of core deposits can be used to mitigate the full effect of tighter monetary policy on their bankdependent borrowers. In this manner, the business strategy of "traditional banks" acts as a "core deposit mitigation channel" to provide funds to bank-dependent borrowers when there are monetary shocks. In effect, there is no bank lending channel of monetary policy associated with these traditional banks.

In contrast, other banks mainly rely on managed liabilities that are priced at market rates. These banks do not have to shift from insured deposits to managed liabilities in response to tighter monetary policy. At the margin, their loans are already funded with managed liabilities. For these banks as well, there is no unique bank lending channel of monetary policy.

The only banks that are likely to raise loan rates substantially in response to an increase in the federal funds rate are banks with a high proportion of relationship loans that are close to a loan-to-core deposit ratio of one. These banks must substitute higher cost nondeposit liabilities, which have an external finance premium, for core deposits, which do not because of deposit insurance. Some of these banks may also face higher marginal costs as their loan-to-core deposit ratio approaches one because of the costs associated with lending to default-prone relationship borrowers.

Thus, our theory suggests that banks with a relatively high proportion of relationship borrowers should have lower loan-to-deposit ratios. Moreover, such banks should increase loan rates more in response to higher market rates when they become close to their core lending capacity. (We define their core lending capacity as the dollar amount of loans that can be funded with core deposits.) Our empirical approach is to estimate a model similar to the one estimated in Kashyap and Stein (2000), but we exploit interaction terms between loan-to-core deposit ratios and the federal funds rate (as a measure of monetary policy).

Our empirical findings are consistent with our theory. We find evidence of a bank lending channel for monetary policy only for banks that specialize in relationship lending and also have a loan-to-core deposit ratio near one - these banks significantly 
reduce lending in response to a monetary contraction. For all other banks, there is no evidence of a bank lending channel.

The remainder of our paper is organized as follows: Section II provides some background on our view of banking. Section III is a description of our strategy to identify a bank lending channel, including a graphical description of the underlying theory. This section provides the intuition behind our empirical approach. Section IV provides the theory more formally. Section $\mathrm{V}$ describes our empirical approach, including the data needed to implement it, and discusses our findings. Section VI extends our analysis to cover some recent themes concerning the bank lending channel, and Section VII concludes with a brief discussion of the implications of our findings.

\section{THE UNIQUe Business OF BANKING}

In this paper, we argue that some banks are special because they have access to deposits with sticky interest rates -- core deposits - and because they focus on relationship or "bank-dependent" borrowers. In our theory, these two business functions are intertwined. Core deposits permit banks to make implicit contractual agreements with bank-dependent borrowers that would be infeasible if they had to pay market-sensitive rates for such funds. ${ }^{1}$ Traditionally, the transmission mechanism for the bank lending channel has focused on core deposits being a relatively low-cost form of bank funding which is not perfectly substitutable with managed liabilities. Here, we change the emphasis to highlight the fact that many banks aggressively pursue core deposits as a distinct and profitable line of business. The availability of core deposits creates the opportunity for banks to mitigate the effects of interest rate shocks on their bankdependent borrowers.

Indeed, empirical evidence suggests that banks funded more heavily with core deposits provide more loan rate smoothing in response to exogenous changes in credit risk (Berlin and Mester, 1999). Moreover, access to core deposits may allow banks to negotiate multi-period state-contingent contracts that are more efficient than singleperiod or multi-period fixed-payoff contracts. For example, banks with greater market

\footnotetext{
${ }^{1}$ Price rigidity in the U.S. market for consumer bank deposits is well established. See, for example, Hannan and Berger (1991), Neumark and Sharp (1992), and Kahn, Pennacchi, and Sopranzetti (1999).
} 
power in their core deposit market(s) may be better positioned to gain an implicit equity interest in new firms (because of a higher probability of lending to successful entrepreneurs in the future) owing to their more stable cost of funds (Petersen and Rajan, 1995). In addition, banks are liquidity providers to their loan commitment customers and to their transactions account depositors. In this dual liquidity provision role, banks typically face increased take-down demands from borrowers constrained by tight market conditions at the same time that they experience deposit inflows (Gatev and Strahan, 2005). This synergy allows banks to hold less liquid assets to fulfill liquidity needs (Kashyap, Rajan, and Stein, 2002). In effect, banks can insure bank-dependent borrowers against systematic declines in liquidity at a lower cost than can other financial institutions.

This is not to say that changes in the cost of managed liabilities are irrelevant. Innovations, such as loan securitization methods, have increasingly enabled banks to provide loans that are funded with managed liabilities at market-based rates to some customers (i.e., those who typically have more collateral or net worth than is held by bank-dependent borrowers). For example, the loan pricing on most conventional, fixedrate, 30-year home mortgages is determined in the national market because such loans are frequently sold to securitizers, such as Fannie Mae and Freddie Mac. Similarly, most credit card loan rates are heavily influenced by secondary markets because most such loans are now securitized using asset-backed securities. Such customers, however, are arguably not bank-dependent, and therefore, would not be unduly influenced by the bank lending channel described above.

We posit that some banks may have a business strategy to provide relationship loans (where they have loan origination and monitoring advantages relative to capital markets) with core deposit funding (where they can pass along the benefit of a sticky price on deposits). These "traditional banks" might invest in excess core lending capacity and thereby circumvent the full effect of tighter monetary policy on their bank-dependent borrowers. In contrast, banks that rely mainly on managed liabilities that are priced at market rates would need to raise lending rates, or tighten lending standards, in response to tighter monetary policy. 


\section{IDENTIFICATION OF A BANK LENDING CHANNEL}

As argued by Kashyap and Stein (1995), a measure of the bank lending channel is how the spread between the bank lending rate and the risk free rate changes in response to a rise in short-term interest rates. If the loan rate increases one-for-one (that is, the spread remains constant), then there is no bank lending channel.

We modify this approach to account for loan default. Clearly, if a borrower can default, then an increase in risk-free interest rates might be associated with an increase in lending rates that exceeds the increase in the risk-free rate. For example, in the balance sheet channel described above, an increase in the market rates causes the value of the borrower collateral to fall and, perhaps, their cash flows to diminish. In response to this deterioration in credit quality, the bank would raise rates more than one-for-one in response to an increase in the risk-free rate. In such circumstances, bank loan rates can rise more than the risk free rate, yet this increase may not be evidence of a pure bank lending channel.

Some bank borrowers might be affected more by an increase in the bank's loan rates than others, and this additional effect might be associated with the unique characteristics of bank lending. We define "relationship borrowers" as borrowers with three characteristics. First, their probability of success is more highly influenced by the bank's loan rate than the probability of success for other borrowers. A higher loan rate noticeably raises their odds of default. Second, relationship borrowers are more costly for these banks because of the interest rate smoothing described above and because these borrowers require more services than other borrowers. Third, relationship borrowers are more likely to engage in opaque activities, which give them a higher external finance premium (making them more reliant on bank loans for financing). ${ }^{2}$ This higher external finance premium also may imply a higher deadweight loss should they default.

Our identification strategy is in the spirit of Kashyap and Stein (2000), who compare the differences in responses to monetary policy between large and small banks, and then look at the differences within each group. As we will show formally in the next section, the characteristics of relationship borrowers create sharply different responses to

\footnotetext{
${ }^{2}$ As a result, banks that fund mainly relationship borrowers may be themselves more opaque, raising the banks' external finance premium as well.
} 
interest rate shocks by banks with large proportions of relationship borrowers when compared to those of banks with low proportions of relationship borrowers. We then compare within each group their response to monetary shocks given their loan-to-core deposit ratios, which are related to the costs of the relationship lending. The Kashyap and Stein (2000) difference-in-difference identification strategy argues that evidence of a bank lending channel can be found by examining how small banks differ in response to monetary shocks based on different holdings of securities holdings. In contrast, our approach argues that evidence of a bank channel can be found by examining how banks with many relationship borrowers differ in response to monetary shocks based on different loan-to-core deposit ratios.

As shown in figure 1, the loan supply functions for high relationship lenders and low relationship lenders are strikingly different. Banks with larger proportions of relationship borrowers - high relationship lenders - charge higher loan rates to cover their borrowers' higher expected default rates and higher relationship costs. However, to the degree that such banks have low loan-to-core deposit ratios, these higher rates can be substantially mitigated. At the lowest loan-to-core deposit ratios, there are fewer loans that incur relationship costs and there is greater capacity to provide lower-cost relationship lending services. As loan-to-core deposit ratios rise, the loan rates change a little for the low relationship lenders (i.e., the banks with a small proportion of relationship borrowers). But for relationship borrowers at high relationship lenders, rates rise quickly because the default rates for these borrowers rise and, at the same, the costs of maintaining the relationships increase.

The response of each relationship lender group to an interest rate shock is shown in figure 2. The low relationship lender group has a smaller response. (The vertical axis describes the multiple of the loan rate relative to the change in the risk free rate. For example, 1.2 means that a 100 basis point increase in the risk free rate increases the loan rate 120 basis points.) At relatively low loan-to-core deposit ratios, both groups show little change in their response to interest rate shocks because deposit funding is readily available for all borrowers (securities holdings are simply decreased to free up the deposits for funding loans). Similarly, at relatively high loan-to-core deposit ratios (those greater than one), high cost market-based funds (nondeposit liabilities) are readily 
available for both high and low relationship lender groups and thus their response to interest rate shocks is unchanging as the loan-to-core deposit ratio increases.

Only when the loan-to-core deposit ratio is close to one does a notable difference in response appear between the groups. (Recall, core deposits here are a short-hand for bank liabilities whose rates embed a minimal external finance premium, such as insured deposits and Federal Home Loan Bank advances.) As loans approach core lending capacity, the odds of default for relationship borrowers rise at the same time that the bank's costs of supporting these relationships increase. These effects interact to push the bank to raise its loan rates all the more as market rates rise. Close to this barrier, the high relationship lenders show an upward tilt in how much they increase loan rates in response to an interest rate shock.

Thus, our theory makes the following predictions:

1. High relationship lenders will have lower loan-to-core deposit ratios than low relationship lenders. (Because lending to relationship borrowers imposes higher market premiums on these banks if they need to switch to nondeposit funding sources.)

2. High relationship lenders who are close to exhausting their capacity to fund loans with deposits will raise loan rates more sharply in response to changes in market interest rates. Thus, their lending should fall more in response to a monetary contraction than other banks. This is a pure bank lending channel effect. ${ }^{3}$

3. All banks - both high and low relationship lenders - that have substantial excess core lending capacity should not vary how they change loan rates in response to a change in market rates. Their costs of funds is not varying in response to market rates; their main cost of higher market rates is the opportunity costs associated with holding fewer securities and the possible deterioration of their borrower's balance sheets. Consequently, it is difficult to identify the pure bank lending channel effects among these lenders.

\footnotetext{
${ }^{3}$ Note that this result is similar to the Kashyap and Stein (1995) bank lending channel effect. High intensity relationship lenders are usually smaller banks and those with high loan-to-core deposit ratios also have low securities-to-asset ratios. Thus, our model and its predictions provide a different interpretation of the Kashyap and Stein (2000) result.
} 
4. All banks - both high and low relationship lenders - that have exhausted their core lending capacity for funding loans should not vary how they change loan rates in response to a change in market rates. For these banks, their marginal funding is already determined in the market and these banks simply pass-through market rate increases. It seems unlikely that a pure bank lending channel exists among these lenders.

\section{A SimPle THEORY OF RELATIONSHIP BORROWING AND CORE DEPOSITS}

We posit that the business of banking is providing core deposits and using those deposits to fund "relationship borrowers." Core deposits are by definition less sensitive to fluctuations in market interest rates (because of deposit insurance) and they have little external finance premium embedded within their costs. Banks have a choice between funding loans using managed liabilities, which are priced at market rates, and funding loans using core deposits. Banks can always raise funds at market rates. Moreover, there is no constraint on banks to substitute market-based funds for core deposits. In a nutshell, we argue that a bank has the capacity and the willingness to fund a relationship borrower under all circumstances, but it is more profitable to fund these loans with core deposits.

\section{LOAN SUPPLY}

The borrower has an exogenous constraint on the amount borrowed, denoted $L^{*}$. The loan is invested in a project that returns $\alpha L$, where $L^{*}$ is the amount borrowed. The project pays $\left(\alpha-r_{L}\right) L$, where $r_{L} L$ is both the interest and principal of the loan. If the project succeeds $\left(\alpha-r_{L}\right)$ is positive. If the project fails, it is negative and the borrower walks away. The probability $q$ that the project pays off is:

$$
q=\int_{r_{L}}^{\infty} f(\alpha) d \alpha
$$

Banks are unique from other financial institutions when they are in the business of "farming" core deposits. This process involves building bank branches, ATMs and 
other methods of handling retail transaction accounts and finding consumers who value convenience and who are generally not sensitive (with their money placed in these accounts) to changes in interest rates. As a result, core deposits rates are relatively low cost and are very sticky in response to increases in market rates.

Banks also fund relationship borrowers. Banks overcome adverse selection problems by investing in a relationship with the borrower and through this process come to know the true default probability for the firm. Moreover, banks smooth interest rate fluctuations for these borrowers because they know changes in loan rates can dramatically influence the odds of success for these borrowers. Such loan rate smoothing can cost the bank money, but this cost is mitigated the more the bank relies on core deposits. If loans are a small portion of core deposits, the marginal increase in the cost of funds is almost zero.

In this business, bank profits depend on core deposit capacity. To collect a given amount of deposits, banks must raise and invest capital, $K$, by paying the market return on equity, $r_{e}$. After making this investment, deposits cost the bank $r_{d}<r_{e}$, where we assume, for convenience, that $r_{d}$ is not influenced in the short-run by fluctuations in market interest rates. Brick and mortar investments place a capacity constraint, $\bar{D}$, on the amount of the core deposits that are collected, $D$, and therefore on the amount of loans that can be funded by core deposits.

Bank profits depend on whether core lending capacity is adequate (that is, whether there are sufficient core deposits to fund the loan portfolio). In a "low demand" environment, banks can retain all the loans they originate. Excess core deposits are invested in market-rate securities where the return is less than the return on loans, or $r_{L}>r_{\text {alt }}$. If the return to the firm's project exceeds the firm's obligation to the bank $\left(\alpha-r_{L} \geq 0\right)$, then the bank receives its promised repayment. If the return to the firm's project falls short, the bank receives the liquidation value of the project, $\delta$.

When loan demand is low relative to core deposits $\left(\bar{D}>L_{L}\right)$, a bank's expected profit on a loan is:

$$
\pi=q r_{L} L_{\text {low }}+(1-q) \delta L_{\text {low }}+r_{\text {alt }}\left(\bar{D}-L_{\text {low }}\right)-\frac{\rho}{2}\left(\frac{L}{\bar{D}}\right)^{2} L-r_{e} K-\frac{r_{d}}{2} \bar{D}^{2},
$$


where $\delta$ is the return given the firm defaults and $\rho$ is the cost of smoothing loan rates, which rises as the dollar value of the loans extended rises and falls as core deposits increase. The costs of smoothing will be lower, or higher, depending on whether loans are above, or below, the bank's deposit capacity, $\bar{D}$.

A bank maximizes profits with respect to the dollar amount of loans extended, which in the low-demand case leads to the first-order condition where the loan rate is:

$$
r_{L}=\frac{r_{a l t}+\rho \frac{3}{2}\left(\frac{L}{\bar{D}}\right)^{2}-(1-q) \delta}{q}
$$

\section{UNDERSTANDING THE BANK LENDING CHANNEL}

In equilibrium, loan supply equals loan demand. Loan demand is a function of the interest rate and the payoff from the firm's investments:

$$
L_{\text {low }}^{S}=L_{\text {low }}^{D}\left(r_{L}, \alpha\right) \text {. }
$$

The equilibrium rate, which is rate observed for the loans on the bank's balance sheet, is:

$$
r_{L}=\frac{r_{\text {alt }}+\rho \frac{3}{2}\left(\frac{L_{\text {low }}^{D}\left(r_{L, q}\right)}{\bar{D}}\right)^{2}-(1-q) \delta}{q} .
$$

Note that if loan payment is certain $(q=1)$, then the loan rate is the same as the market rate (and because there is no motivation for loan smoothing, $\rho=0$ ). In this case, there is no bank lending channel, and the loan rate equals the market rate.

The bank lending channel describes how the interest rate on loans changes in response to an increase in market interest rates (created by the Federal Reserve or other exogenous events). Taking the total derivative of equation (4) with respect to $r_{a l t}$ and rearranging terms yields 


$$
\frac{\partial r_{L}}{\partial r_{a l t}}=\frac{1}{q-\rho \frac{3}{\bar{D}}\left(\frac{L}{\bar{D}}\right) \frac{\partial L_{\text {Low }}^{D}}{\partial r_{L}}+\frac{\partial q}{\partial r_{L}}\left[\frac{r_{\text {alt }}+\rho \frac{3}{2}\left(\frac{L_{\text {low }}^{D}\left(r_{\text {alt }}, q\right)}{D}\right)^{2}-\delta}{q}\right]}
$$

If loan demand is held constant (and thus $\frac{\partial L_{\text {Low }}^{D}}{\partial r_{L}}=0$ ) and the firm has no probability of default, then $\frac{\partial r_{L}}{\partial r_{a l t}}=1$. An increase in market interest rates is directly reflected in the loan rate and there is no bank lending channel for monetary policy. If the firm can default on its loan, but there is no relationship between the probability of the firm's default and the loan rate, then $\frac{\partial r_{L}}{\partial r_{\text {alt }}}=\frac{1}{q}$ (which is how a non-bank provider of loans funded by the capital markets would respond to rate changes). In contrast, for banks with relationship borrowers the loan rate is "marked-up" to reflect the probability of default, loan demand, and the costs of interest rate smoothing. The bank channel is stronger when borrowers are relationship firms with higher probabilities of default and inelastic demands for loans.

Traditionally, the bank lending channel is described as resulting from an increase in the cost of liabilities as banks shift from lower-cost core deposits to other higher-cost liabilities. But in a world of low loan demand, core deposits are plentiful and their marginal cost is effectively zero. In such a circumstance, raising the loan rate increases the gross revenues of the bank but also raises the likelihood of default for the borrower, causing the bank to pass through more than the market rate increase to compensate for this additional cost. ${ }^{4}$

\footnotetext{
${ }^{4}$ There are a variety of newer proposals about how a banking channel might work. These theories are much more elaborate that the one presented here. Our simple theory, however, does describe some of the important elements behind these theories. For example, Van den Heuvel (2007) argues that bank capital is key to a bank lending channel. In our theory, low bank capitalization would increase a bank's external finance premium, enhancing the bank channel for banks with small loan-to-core deposit ratios. Freixas and Jorge (2007) model a "rationing channel" by postulating imperfections in the interbank market for
} 
But large amounts of core deposits can limit this additional loan rate increase. If loan demand is very inelastic, then the change in the impact of the bank lending channel can be mitigated by a low loan-to-core deposit ratio or:

$$
\left.\left.\frac{\partial\left(\frac{\partial r_{L}}{\partial r_{\text {alt }}}\right)}{\partial\left(\frac{L}{\bar{D}}\right)}=\frac{-1}{\left.q+\frac{\partial q}{\partial r_{L}}\left[\frac{r_{\text {alt }}+\rho \frac{3}{2}\left(\frac{L_{\text {low }}^{D}\left(r_{\text {alt }}, q\right)}{\bar{D}}\right)^{2}-\delta}{q}\right]\right]^{2}}\right] \frac{\rho \frac{3}{\bar{D}} \frac{\partial q}{\partial r_{L}}\left[\frac{L_{l o w}^{D}\left(r_{\text {alt }}, q\right)}{\bar{D}}\right]}{q}\right]>0 .
$$

A relationship borrower is one where the probability of default is higher (lower $q$ ), the costs of default are larger (smaller $\delta$ ), the costs of interest rate smoothing are larger ( $\rho$ is larger), the increase in the probability of default is larger in response to an increase in their loan rate $\left(\frac{\partial q}{\partial r} \ll 0\right)$, and where the firm is heavily bank dependent for financing $\left(\frac{\partial L^{D}}{\partial r_{L}} \approx 0\right.$, not $\left.\frac{\partial L^{D}}{\partial r_{L}} \ll 0\right)$. For high relationship lenders, all of these features imply that the bank raises loan rates more in response to an increase in market rates (relative to the loan rate increase for other borrowers) to recover the higher costs associated with relationship lending.

However, high relationship lenders can mitigate this cost by building a large core lending capacity. By keeping $\frac{L}{\bar{D}}$ relatively low, the effect of the bank lending channel is somewhat lessened because the multiple of the interest rate increase for borrowers is reduced. Thus, within the high relationship lender group, one might expect to see lower

reserves, and combine this model with relationship borrowers to generate a bank lending channel. Imperfections in the interbank market effectively raise the external finance premium for banks. This higher premium combined with relationship borrowers who can not shift to other sources of financing would amplify the bank channel in our theory as well. Finally, Diamond and Rajan (2006) present a "liquidity" channel that arises because of mismatches between the real economy's demand for loans and the nominal value of deposits. Fluctuations in the real economy or fluctuations created by monetary policy alter the payoff structure of the firms' projects. Here, these fluctuations would change $q$, which might strengthen or weaken the bank channel described above. 
loan-to-core deposit ratios and a more pronounced increase in the drop in loan supply that occurs in response to an interest rate increase (as the loan-to-core deposit ratio increases).

\section{HigH LOAN DEMAND}

In the case of high loan demand $\left(\bar{D}<L_{L}\right)$, the bank must turn to market-based funding (that is, nondeposit liabilities) to lend at the margin. It cannot rely exclusively on its core deposits. Market-based funds are provided to bank j at a rate $r_{a l t}+\phi_{j}$, where $\phi_{j}$ is a market premium that reflects the risks associated with lending to the bank. It seems reasonable that a bank that is more focused on relationship borrowers (a high relationship lender) might have a higher credit risk premium embedded in its nondeposit lending (a higher $\phi$ ).

With high loan demand, a bank's expected profits on a loan is:

$$
\pi=q r_{L} L_{\text {High }}+(1-q) \delta L_{\text {High }}-\left(r_{\text {alt }}+\phi_{j}\right)\left(L_{\text {High }}^{D}-\bar{D}\right)-\frac{p}{2} \bar{D}-r_{e^{*}} K-\frac{r_{d}}{2} \bar{D}^{2},
$$

which implies that the yield on a bank's loans is:

$$
r_{L}=\frac{r_{\text {alt }}+\phi_{j}-(1-q) \delta}{q} .
$$

In this case, the change in loan rates with respect to market rates is:

$$
\frac{\partial r_{L}}{\partial r_{\text {alt }}}=\frac{1}{q+\frac{\partial q}{\partial r_{L}}\left[\frac{r_{a l t}+\phi_{j}-\delta}{q}\right]},
$$

which is positive.

\section{LOAN SUPPLY AND LONG-RUN CORE LENDING CAPACITY}

Core lending capacity is fixed in the short-run. Loan smoothing costs are linked to deposits because deposits have almost no marginal costs. In the long-run, the bank would like its loan-to-core deposit ratio to be as small as possible (that is, it wants a big core lending capacity) so long as the marginal profitability of additional core lending capacity does not exceed the marginal costs of using market-based funds. Thus, long-run core lending capacity is: 


$$
\bar{D}=\frac{r_{a l t}+\phi_{j}-\frac{\rho}{2}}{r_{d}}
$$

At the margin, a bank compares the costs associated with relationship borrowers to the external financing costs (including the external finance premium) associated with nondeposit funding. If the external finance premium is high and the costs associated with relationship borrowers are low, the bank will desire a larger deposit capacity relative to loans (that is, a smaller $\frac{L}{\bar{D}}$ ). Thus, high relationship lenders typically desire smaller loan-to-core deposit ratios, and low relationship lenders typically would prefer bigger loan-to-core deposit ratios.

\section{OUR EMPIRICAL APPROACH}

DATA. This section describes the data sources and the data elements that were constructed to estimate our empirical model and to stratify banking organizations into different relationship lending groups. We describe (1) the balance sheet data for individual banks, (2) the reasons for and methods used to aggregate such information for entities that are subsidiaries within a bank holding company, (3) the factors used to control for regional and macroeconomic conditions, and (4) the data used for the stratification strategy that is implemented prior to the estimation of the empirical model. Then, we take a brief look at the stratified data across time before discussing the specification of the model that was estimated.

Bank Balance Sheet Information. We used Call Reports for individual, federally-insured, domestically chartered commercial banks to construct quarterly data for eight bank balance sheet variables consisting of four lending activity measures commercial and industrial loans (C\&I), relationship-based business loans (RBL), residential mortgages (MORT), and total loans (LOANS) - securities (SEC), core deposits (DEP), equity capital (K), and total assets (A). These data were constructed for the period 1991:Q4 - 2005:Q4, inclusive, since the data used to create RBL are not available prior to $1993: Q 2 .^{5}$

\footnotetext{
${ }^{5}$ Because RBL is only used to stratify banks, we were able to take other data back earlier to use as lags in the empirical model.
} 
The two business lending categories, C\&I and RBL, each include only loans to businesses domiciled in the United States. C\&I is the amount outstanding of all such business loans, regardless of their original amount. ${ }^{6}$ In contrast, RBL is defined to be business loans with original amounts of $\$ 1$ million or less. ${ }^{7}$

Residential mortgages (MORT) include (1) the amount outstanding of all permanent loans secured by 1-to-4 family residential properties, and (2) the amount outstanding of loans extended under revolving, open-end lines of credit secured by 1-4 family residential properties. ${ }^{8}$ Such open-end lines of credit, commonly referred to as "home equity lines," are typically secured by a junior lien and are usually accessible by check or credit card. ${ }^{9}$ As with C\&I loans, we included only domestic mortgage loans in our measure of mortgage lending.

In contrast, total loans (LOANS) are measured on a consolidated basis (i.e., both domestic and foreign loans are included). This comprehensive lending measure equals the aggregate book value of all loans made by the bank (before the deduction of valuation reserves). ${ }^{10}$

Securities (SEC) are also measured on a consolidated basis, since either domestic or foreign securities could potentially be liquidated by a bank to fund its lending activities. SEC includes securities classified by the bank as "held-to-maturity" or "available-for-sale." ${ }^{\text {11 }}$ In addition, SEC includes balance sheet (liquid) assets that were

\footnotetext{
${ }^{6}$ C\&I = RCON1763. (RCON is the Call Report mnemonic for domestic balance sheet and income statement information for banks. RCFD is the Call Report mnemonic for both domestic and foreign information for banks.) For banks with less than $\$ 300$ million in assets and no foreign branches, this item is only reported on a consolidated basis (i.e., commercial and industrial loans = RCFD1766).

7 RBL = RCON5571+RCON5573+RCON5575. Call Report data break out three size categories: (1) loans with original amounts of $\$ 100,000$ or less, (2) loans with original amounts of more than $\$ 100,000$ through $\$ 250,000$, and (3) loans with original amounts of more than $\$ 250,000$ through $\$ 1,000,000$.

${ }^{8}$ MORT $=$ RCON1797+RCON1798.

${ }^{9}$ The reported value on the Call Report is the amount outstanding as of the report date, not the total amount that the customer is authorized to borrow under such arrangements.

${ }^{10}$ LOANS=RCFD1400.

${ }^{11}$ Using generally accepted accounting principals (GAAP), securities that are "held-to-maturity" are included at their amortized cost, but securities "available-for-sale" are included at their fair value. This measurement convention for securities is consistent with how each security group influences a bank's profitability and its capitalization.
} 
booked as trading assets, federal funds sold, and securities purchased under agreement to resell. $^{12}$

Core deposits (DEP) consist of deposits collected at domestic offices. These deposits include transaction accounts, non-transaction savings deposits, and total time deposits less than $\$ 100,000$. $^{13}$

Equity capital (K) includes common stock, perpetual preferred stock, surpluses, undivided profits and capital reserves. ${ }^{14}$ And the variable, total assets (A), provides a measure of the balance sheet size of each bank. ${ }^{15}$ These items, measured on a consolidated basis, were used to calculate bank-specific capital-to-asset ratios.

TOP Holder BALANCE SHEEt InfORMATION. There is considerable evidence that bank holding companies establish internal capital markets in an attempt to allocate capital among their subsidiaries. For example, the loan growth of banks within a bank holding company is less sensitive to cash-flow and capital at the bank than is loan growth at banks that are not affiliated with a bank holding company (Houston and James, 1998). The converse is also true: Loan growth at subsidiary banks has been found to be more sensitive to the bank holding company's cash flow and capital than to the bank's own cash flow and capital (Houston, James, and Marcus, 1997).

Given this evidence, we used the individual bank balance sheet data described above to construct top holder balance sheet data for our analysis. For example, a bank holding company, which is comprised of a lead bank and several subsidiary banks, would be the top holder of the banking organization. We aggregated individual bank asset and liability information to the domestic top holder level using information from the National Information Center (NIC), which is the central repository containing information about

\footnotetext{
12 The time-series for securities holdings was measured on a comparable basis through time as follows: Prior to March 1994 (SEC = RCFD0390 + RCFD2146 + RCFD1350), between March 1994 and March 2002 (SEC = RCFD8641 + RCFD3545 + RCFD1350), between March 2002 and March 2003 (SEC = RCFD8641 + RCFD3545 + RCONb987+RCFDb989) and after March 2003 (SEC = RCFD8641 + RCFD3545 + RCFDb987 + RCFDb989).

${ }^{13}$ DEP $=$ RCON2702.

${ }^{14} \mathrm{~K}=$ RCFD3210. Also included in equity capital are cumulative foreign currency translation adjustments less net unrealized loss on marketable equity securities.

${ }^{15} \mathrm{~A}=$ RCFD2170.
} 
all U.S. banking organizations and their domestic and foreign affiliates. ${ }^{16}$ A bank that is unaffiliated with any other bank is considered to be its own top holder organization. For ease of exposition, henceforth we will refer to the top holder organizations as either entities or banks.

Deposit Market ConCentration. Deposit market competition might influence the size of the external finance premium faced by a bank as it moves from insured to uninsured liabilities. Changes in the federal funds rate effects on bank lending have been found to be greater in less concentrated deposit markets, which tend to be urban, than in more concentrated deposit markets, which tend to be rural (Adams and Amel, 2005, Jayaratne and Morgan, 2000). However, using measures of deposit market competition to identify the bank channel is difficult because rural bank borrowers might experience more balance sheet deterioration in response to a monetary contraction than urban-based bank borrowers, confounding any test for the bank channel. Thus, in our base empirical model, we use such measures only as a market control measure and do not explore interactions between these measures and monetary policy. In the extensions to our analysis at the end of this paper, we examine the interaction effects between our measure of monetary policy and a measure of deposit market competition.

For each entity, we constructed a deposit-weighted Herfindahl-Hirshmann index (HHI) to proxy for deposit market competition. ${ }^{17}$ As is standard practice, geographic banking markets were approximated by economically integrated local areas: Urban markets were defined as Metropolitan Statistical Areas (MSAs) and rural markets were defined as state-counties. Branch level deposit data were used to construct a HerfindahlHirshmann index for each of these U.S. geographic banking markets. ${ }^{18}$ This index,

\footnotetext{
16 To prevent the double-counting of assets or liabilities, banks that filed Call Reports that were consolidated upward were removed.

${ }^{17}$ Using a simple average, rather than a deposit-weighted average, for the Herfindahl-Hirshmann index for each entity did not qualitatively affect the results presented below.

${ }^{18}$ Information about the locations of branches (including head offices) and the deposits held by each depository institution in each local market were obtained from the Federal Deposit Insurance Corporation's Summary of Deposits (for commercial banks) and the Office of Thrift Supervision's Branch Office Survey (for thrifts). These data are available annually, so the Herfindahl-Hirshmann indexes calculated for each geographic market are constant across quarters within each year. The authors thank Robin Prager for providing quarterly Herfindahl-Hirshman indexes for each U.S. bank over 1986-2005.
} 
calculated as the sum of market deposit shares, increases as the market concentration in the geographic region rises. ${ }^{19}$ For each entity, the deposit-weighted HHI was constructed using its allocation of deposits across the geographic markets it participated in and the Herfindahl-Hirshmann indexes that were calculated for those geographic markets. ${ }^{20}$

Macroeconomic and Regional Conditions. National economic conditions were measured using (seasonally-adjusted) real GDP. ${ }^{21}$ And to allow economic conditions to vary across geographic regions, we included 12 Federal Reserve-district fixed effects.

As an indicator of monetary policy, we used the federal funds rate (FFR). ${ }^{22}$ This measure has been used by a variety of researchers (e.g., Bernanke and Blinder (1992) and Kashyap and Stein (2000)). Moreover, studies like Bernanke and Mihov (1998) suggest that the funds rate is an appropriate measure of policy during the period we examine. Higher values of this indicator correspond to tighter policy.

In addition, note that in our model, the lender is responding to movements in its cost of funds. Thus, endogenous and anticipatory movement in the federal funds rate that distort measures of the true stance of monetary policy influence the lender and are transmitted through the bank channel (see Romer and Romer, 2004). But for our purposes, these changes in the federal funds rates still can be used to measure the importance of the bank channel. If changes in the federal funds rate do not influence loan rates, then whether or not such changes were an intended change in monetary policy is irrelevant. If such changes are important, then the channel exists even if it sometimes transmits federal funds rate changes that do not reflect the true stance of monetary policy.

\footnotetext{
${ }^{19}$ For the analysis presented below, commercial bank deposits received a $100 \%$ weight and thrift deposits received a $50 \%$ weight in this calculation. However, only using commercial bank deposits in the calculation of the Herfindahl-Hirshmann indexes for each geographic market did not qualitatively influence these results.

${ }^{20}$ In some specifications, we divided the deposit-weighted HHI by 1800 - the Federal Trade Commission definition of a competitive market. In other specifications, we set all deposit-weighted HHIs less than 1800 to one and all deposit-weighted HHIs greater than 1800 to the scaled deposit-weighted HHI. These changes to the entity-level concentration measure also did not qualitatively influence the reported results.

${ }^{21}$ We used the chained index for real GDP that is in year 2000 dollars.

${ }^{22}$ Our bank balance sheet data is quarterly. We use the average federal funds rate for the last month of each quarter for the value of the quarterly federal funds rate as was done in Kashyap and Stein (2000).
} 
RELATIONSHIP LENDER STRATIFICATION. Using the June Call Report in each year, entities were stratified into three relationship lending groups for the entire calendar year. First, a "relationship lending intensity score" with respect to business loans for each entity was calculated by taking the ratio of RBL-to-C\&I. Entities that only originated business loans with original amounts of $\$ 1$ million or less had relationship lending intensity scores equal to one. In contrast, entities that made only a small fraction of their business loans with original amounts of $\$ 1$ million or less had relationship lending intensity scores close to zero. ${ }^{23}$

Second, entities were rank-ordered by their relationship intensity score from lowest to highest score. The distribution of relationship intensity scores is highly skewed, with a large number of banks having scores equal to one. Entities that received a relationship intensity score that was greater than or equal to the fifth percentile of the relationship lending intensity score distribution were placed in the "high relationship lender" group. Entities that received a relationship lending intensity score that was less than the fifth percentile, and also greater than or equal to the first percentile of the relationship lending intensity score distribution, were placed in the "medium relationship lender" group. The remaining entities, those that received a relationship lending intensity score so small that it was less than the score that was at the first percentile of the relationship lending intensity score distribution, were placed in the "low relationship lender" group. This entity stratification procedure ensured that only entities with a relatively small proportion of their business loans originated in amounts less than or equal to \$1 million would be included in the "low relationship lender" group.

Figure 3 provides the relationship lending intensity score cutoffs in each year of the sample. High relationship lenders had more than 40 percent of their domestic C\&I lending originated in amounts less than \$1 million throughout the sample. In contrast, low relationship lenders had less than 20 percent of their domestic C\&I lending originated in amounts less than $\$ 1$ million by the end of the sample period.

\footnotetext{
${ }^{23}$ Peek and Halod (2006) used June bank call reports to identify the contribution of lending relationships to the market values of banking organizations. They report that each dollar of small commercial and industrial loans -- business loans originated in amounts less than \$1 million -- held in a bank's portfolio adds just over eight cents to the market value of the banking organization relative to large commercial and industrial loans (defined as business loans originated in amounts greater than \$1 million).
} 
Relationship borrowers may or may not be more prone than other borrowers to experience balance sheet deterioration in response to a monetary shock. On one hand, such borrowers may tend to be smaller and less diversified than other borrowers. On the other hand, such borrowers might work in market niches or have market power that nonrelationship borrowers do not have. Regardless, it seems unlikely that borrowers who are more prone to balance sheet deterioration would sort themselves by banks' loan-to-core deposit ratios. Thus, we believe that our empirical approach uniquely identifies a bank loan supply effect and not changes in the financial conditions of borrowers.

Asset Size is not a Proxy for Relationship Lending Intensity. Figure 4 shows box-plots for the distribution of total assets (measured in nominal dollars) in the second quarter of each year for each of the three relationship groups (high, medium, and low). ${ }^{24}$ These box plots are graphical representations of the center and width of bank asset size distributions, with the height of each box being equal to the interquartile width, which is the difference between the third and first quartile of data. For each second quarter, this width widens considerably as one moves from the high-, to the medium-, to the low-relationship group. The brackets([]) for each box are located at the extreme values of the data for the quarter or at a distance equal to 1.5 times the interquartile distance from the center, whichever is less. ${ }^{25}$ In all second quarters of the sample period, brackets for the low lender relationship group are outside of the brackets for the medium lender relationship group, which in turn are outside the brackets for the high relationship lender group. Therefore, high relationship lenders tend to have the smallest balance sheets and low relationship lenders tend to have the largest balance sheets, but some of the low relationship lenders are quite small as far as asset size is concerned - as small as lenders in the high relationship group.

Although many researchers have used balance sheet size as a proxy for engaging in relationship lending activities, with low asset values associated with specialization in relationship loans and high asset values associated with a dearth of relationship loans, the data presented in figure 4 suggests that this practice is problematic: Banks large and

\footnotetext{
${ }^{24}$ The RBL variable is only available in the second quarter of each year.

${ }^{25}$ For data having a Gaussian distribution, approximately 99.3 percent of the data fall inside the brackets. Thus, only unusually deviant data points fall outside of the brackets.
} 
small may have low proportions of their business loans that are originated in amounts less than $\$ 1$ million dollars. ${ }^{26}$

High Relationship Lenders have LaRge Core Lending CAPACities. For each of the three relationship lending groups (high, medium, and low), figure 5 presents quarterly information on the distribution of core lending capacities -- measured by the ratio of total loans-to-core deposits. A core lending capacity value less than 1 implies that the bank (i.e., top holder) can fund its entire lending portfolio with core deposits. However, when the core lending capacity is greater than one, the bank must use additional funding sources (other than core deposits) to fund its lending portfolio.

The top panel of figure 5 contains the $25^{\text {th }}$ percentiles of the core lending capacities observed for each relationship lender group in each year-quarter. During the sample period, the loan-to-core deposit ratio at the $25^{\text {th }}$ percentile for the high relationship lenders (represented by the blue ball-and-chain line) was always less than the loan-to-core deposit ratio for the $25^{\text {th }}$ percentile for the medium relationship lenders (represented by the solid green line). In addition, the loan-to-core deposit ratio at the $25^{\text {th }}$ percentile for the low relationship lenders (represented by the dashed red line) was typically larger than the loan-to-core deposit ratio at the $25^{\text {th }}$ percentile for the medium relationship lenders (represented by the solid green line).

The middle panel of figure 5 contains the median core lending capacities observed for each relationship group in each year-quarter. The median ratio of loans-to-core deposits for the high relationship lenders (blue ball-and-chain line) is smaller than the median ratio of loans-to-core deposits for the medium relationship lenders (green solid line), which in turn is smaller than the median ratio of loans-to-core deposits for the low relationship lenders (red dashed line). It is also noteworthy that the median loans-to-core deposits ratio is greater than one for the low relationship lenders in every year-quarter of the sample period. Thus, more than half of the low relationship lenders used a funding source other than core deposits to fund their lending portfolio in each year-quarter of the sample period. In contrast, the median loans-to-core deposits ratio for the high

${ }^{26}$ This result is consistent with Kashyap and Stein (1995), who note that size is a poor method of identifying the bank channel because large banks tend to lend to large customers, whose balance sheets may deteriorate less during an economic downturn. Thus, the smaller decline in loans at large banks in response to a monetary contraction may reflect both the large banks' easier access to nondeposit sources of funds and the financial strength of their borrowers' balance sheets. 
relationship lenders was less than one in every year-quarter up until 2005:Q2. This means that more than half of the high relationship lenders could fund their entire lending portfolio with core deposits during most of the year-quarters of the sample, suggesting that they are unlikely to incur an external finance premium when market interest rates rise.

The bottom panel of figure 5 contains the $75^{\text {th }}$ percentiles of the core lending capacities observed for each relationship lending group in each year-quarter. The rankings for these percentiles across groups in each year-quarter are similar to those present in the top and middle panels of figure 5: The $75^{\text {th }}$ percentile of the loan-to-core deposit ratio is smallest for the high relationship lenders and largest for the low relationship lenders. In fact, the lenders in the $75^{\text {th }}$ percentile of the loan-to-core deposits ratio for the low relationship lenders group in each year-quarter always had a loan-to-core deposits ratio greater than 3.0. This means that for one-quarter of the low relationship lender group in each year-quarter, less than a third of the loan portfolio was funded by core deposits.

Looking across the panels of figure 5 it is clear that the distribution of loan-tocore deposit ratios for the high relationship lender group in each year-quarter is more tightly distributed and is centered to the left of the corresponding distributions for the medium- and low-relationship lender groups.

How Many Banks are Constrained by their CoRe Lending Capacity? Consider the information presented in table 1, which presents the proportion of banks by their relationship lending status and by three ranges for loan-to-core deposit ratios. When a bank's loan-to-core deposit ratio is less than 0.8 , it is highly likely that it can continue to lend without turning to nondeposit liabilities. About 30 percent of the sample observations are for banks with loan-to-core deposit ratios less than 0.8 (top panel, fourth row, first column).

Once a bank's loan-to-core deposit ratio is greater than 1.1, it seems unlikely to fund the lending portfolio entirely with core deposits. In fact, a bank with such a loan-tocore deposit ratio is using (uninsured) nondeposit liabilities to fund at least 10 percent of its loans. About 32 percent of the sample observations are for banks that have loan-tocore deposit ratios above 1.1 (top panel, fourth row, third column). 
In the middle range, where the loan-to-core deposit ratio falls between 0.8 and 1.1, a bank is arguably running out of core deposits to fund its loan portfolio and is starting, or has started, to tap nondeposit sources of funds. Almost 39 percent of the sample observations were banks with loan-to-core deposit ratios in the middle range (top panel, fourth row, second column). Most of these banks were included in the high relationship group (equal to 37.6 percent of all banks, second column, top row). Although their number is large, these banks account for just 6 percent of U.S. banking assets.

Consider next the bottom panel of table 1. The first row presents the proportion of high relationship lenders that were in each of the three core lending capacity ranges. About 30 percent of such lenders had loan-to-core deposit ratios that are either below 0.8 or above 1.1. The remainder of such lenders - about 40 percent - had loan-to-core deposit ratios in the middle range.

The second row of the bottom panel of table 1 presents the proportion of medium relationship lenders that were in each of the three core lending capacity ranges. Only 12.5 percent of such lenders had loan-to-core deposit ratios under the 0.8 threshold. And most such lenders, 58.5 percent, had loan-to-core deposit ratios above the 1.1 threshold. Less than 30 percent of the medium relationship lenders were in the middle range of loan-to-core deposit ratios.

The last row of table 1 presents the proportions of low relationship lenders that fell into the three core lending capacity ranges. Less than 8 percent of the lenders stratified into this relationship lending group had a loan-to-core deposit ratio under 0.8. Only about 14 percent were in the middle range of loan-to-core deposit ratios. And the vast majority of these lenders - almost 80 percent - used nondeposit liabilities to fund more than ten percent of the loan portfolio.

Looking across the relationship lender groups, the proportion with loan-to-core deposit ratios less than 0.8 falls monotonically as one peruses down the first column from high relationship lenders to low relationship lenders. This pattern is also true when one considers the 0.8 to 1.1 loan-to-core deposit ratio range (bottom panel, second column). In contrast, the proportion of banks that at the margin use nondeposit funding for their 
loan portfolio rises sharply as the relationship lending intensity declines (bottom panel, third column).

Importantly, the information presented in figure 5 and in table 1 is consistent with the first prediction of our model: High relationship lenders generally have significantly lower loan-to-core deposit ratios than low relationship lenders. With this correlation in mind, it is time to consider a more formal empirical model.

SPECIFICATION OF AN ECONOMETRIC MODEL. Let $L_{i t}$ be the bank-level measure of lending activity at bank $i$ at time $t, C_{i t}$ be the level of the core lending capacity measure at bank $i$ at time $t$ (e.g., $C_{i t}=L O A N S_{i t} / D E P_{i t}$ ), and $R_{t}$ be the monetary policy indicator (with higher values of $R_{t}$ corresponding to tighter policy at time $t$ ). After stratifying the data into relationship lender groups (high, medium, and low) and by core lending capacity $\left(C_{i t}<0.8,0.8 \leq C_{i t} \leq 1.1, C_{i t}>1.1\right)$, we estimated the following relationship: ${ }^{27}$

$$
\begin{aligned}
\Delta \log \left(L_{i t}\right)= & \sum_{j=1}^{4} \alpha_{j} \Delta \log \left(L_{i, t-j}\right)+\sum_{j=0}^{4} \mu_{j} \Delta R_{t-j}+\sum_{j=0}^{4} \pi_{j} \Delta G D P_{t-j}+\Theta T I M E_{t}+\sum_{k=1}^{3} \rho_{k} Q U A R T E R_{k}+ \\
& \sum_{k=1}^{12} \Psi_{k} F R B_{i k}+H H I_{i, t}+C_{i, t-1}\left\{\eta+\delta T I M E_{t}+\sum_{j=0}^{4} \phi_{j} \Delta R_{t-j}+\sum_{j=0}^{4} \gamma_{j} \Delta G D P_{t-j}\right\}+\varepsilon_{i t}
\end{aligned}
$$

where $G D P_{t}$ is real gross domestic product at time $t$, TIME is a time trend, $\operatorname{QUARTER}_{k}(\mathrm{k}=1,2,3)$ are three quarterly indicator variables, $F R B_{k}(\mathrm{k}=1, \ldots, 12)$ are the 12 regional indicator variables, and $H H I_{i t}$ is the deposit market concentration measure for bank $i$ at time $t$.

The derivatives of the estimating equation depend on the cross-sectional and timeseries relationships within the data. The cross-sectional derivative, $\partial L_{i t} / \partial C_{i, t-1}$, captures the sensitivity of bank lending to the core lending capacity that is available. The timeseries derivative $\partial L_{i t} / \partial R_{t}$ measures the sensitivity of lending volume at bank $i$ to monetary policy. And the derivative $\partial^{2} L_{i t} / \partial C_{i, t-1} \partial R_{t}$ exploits both the cross-sectional

\footnotetext{
${ }^{27}$ The error structures were assumed to be heteroskedastic and possibly autocorrelated up to four lags. As a result, we used Newey-West standard errors for the coefficients.
} 
and time-series aspects of the data. Suppose two high relationship lenders are alike except that one is close to exhausting its capacity to fund loans with deposits (i.e., $C_{i t} \rightarrow 1.0$ ). (And recall that we focus on high relationship lenders because their marginal costs rise more than other lenders in response to a given interest rate shock.) Now suppose that these lenders are hit by a contractionary monetary shock. In response to that shock, our model predicts that the lender that is close to exhausting its capacity will reduce its lending more than the other lender. Thus, for high relationship lenders that are close to exhausting their capacity to fund with deposits, it is expected that the sensitivity of their lending volume to monetary policy is greater than for other high relationship lenders with less core lending capacity (i.e., $\partial^{2} L_{i t} / \partial C_{i, t-1} \partial R_{t}<0$ ).

For lenders that have substantial excess core lending capacity and for lenders that have exhausted their deposit capacity for funding loans, it's a different story. When there is a contractionary monetary shock, the lenders with substantial excess core lending capacity are more likely to be influenced by the opportunity costs associated with holding fewer securities and the possible deterioration of their borrowers' balance sheets and less likely to be influenced by the higher costs imposed by an external finance premium. Because of these considerations, it is difficult to identify a pure bank lending channel among such lenders, regardless of whether they specialize in relationship lending.

As for the lenders that have exhausted their deposit capacity, when they experience a contractionary monetary shock, they will not be shifting from deposit funds to nondeposit liabilities. Their marginal funding costs already are completely determined by the market. Consequently, it is also difficult to identify a pure bank lending channel for these lenders, regardless of their relationship lender group status. Thus, for lenders that have substantial excess core lending capacity and for lenders that have exhausted their deposit capacity for funding loans, the sensitivity of lending volume to monetary policy is more difficult to detect even when using longitudinal data.

\section{EMPIRICAL FINDINGS}

Table 2 presents estimates of the partial cross-derivatives of bank C\&I lending with respect to core lending capacity and the monetary policy indicator, i.e., 
$\partial^{2} L_{i t} / \partial C_{i, t-1} \partial R_{t}$, for nine groups of lenders stratified by relationship lender status (high, medium, and low) and by core lending capacity $\left(C_{i t}<0.8,0.8 \leq C_{i t} \leq 1.1, C_{i t}>1.1\right)$. Each of these partial derivatives was evaluated at the sample means of the data used in estimation. ${ }^{28}$

The first column of table 2 reports the partial cross-derivatives of bank C\&I lending with respect to core lending capacity and the monetary policy indicator for banks with substantial excess core lending capacity $\left(C_{i t}<0.8\right)$. None of these derivatives is statistically significant from zero, regardless of whether the lender is a high-, medium-, or low-relationship lender. Since such lenders are not substituting nondeposit funding for deposits at the margin, these results are expected.

The second column of table 2 reports the partial cross-derivatives of bank C\&I lending with respect to core lending capacity and the monetary policy indicator for banks that have loan-to-core deposit ratios near one $\left(0.8 \leq C_{i t} \leq 1.1\right)$. In this column only the partial cross-derivative for the high relationship lenders is negative and it is statistically different from zero at the five percent level. This relationship conforms to expectations: The sensitivity of lending volume to monetary policy is greater for the high relationship lenders with less core lending capacity, i.e., $\partial^{2} L_{i t} / \partial C_{i, t-1} \partial R_{t}<0$. Moreover, the difference between the partial cross-derivative for high relationship lenders and the partial crossderivative for low relationship lenders is statistically significant at the 10 percent level.

The third column of table 2 reports the partial cross-derivatives of bank C\&I lending with respect to core lending capacity and the monetary policy indicator for banks that already rely on nondeposit funds at the margin $\left(C_{i t}>1.1\right)$. Consistent with our theory, it is difficult to detect the presence of a bank lending channel for these lenders, regardless of how intensively they provide loans that are less than $\$ 1$ million at

\footnotetext{
${ }^{28}$ The results provided below are robust to tightening or loosening the range of core lending capacity for banks that have loan-to-core deposit ratios near one. Of course, once the range gets large, banks would not be shifting from core deposit funding to higher cost nondeposit funding. In addition, the reported results are robust to whether we included or excluded C\&I loans less than $\$ 100,000$ in the stratification of relationship lender groups. Suppose that lenders with C\&I loans less than $\$ 100,000$ were predominantly credit card lenders. In such circumstances, exclusion of such lenders from the definition of high relationship lenders would seem appropriate. Regardless of whether we included or excluded such lenders, identical patterns with respect to statistical significance and positive and negative signs for the partial crossderivatives of bank C\&I lending with respect to core lending capacity and the monetary policy indicator were obtained.
} 
origination. In this column, only the partial cross-derivative for the low relationship lenders is significant at conventional levels of significance. And that partial crossderivative is relatively small and positive. Tighter monetary policy is associated with statistically elevated C\&I lending at these lenders when they have higher loan-to-core deposit ratios.

For these low relationship lenders, the high loan-to-core deposit ratio is usually much greater than one. Thus, higher interest rates are not likely to shift these banks to sources of funds with higher external finance premiums. We conjecture that perhaps these lenders are specialists at intermediating between market-priced sources of funds and borrowers who have many other sources of funding besides bank loans. It may be that these banks are able (by hedging and making markets in derivatives) to mitigate the effects of rising rates for these borrowers more than the borrowers can hedge for themselves directly.

\section{EXTENSIONS OF OUR ANALYSIS}

The Role of Securities Holdings. As discussed earlier, Kashyap and Stein (2000) emphasize the role of securities holdings by smaller banks to mitigate their lack of access to nondeposit, market-priced funding sources. In our model, securities holdings are large when loans-to-core deposits are small; securities holdings are simply a place to "park" excess deposits. Thus, similar to Kashyap and Stein (2000), in our model a bank may draw down its securities holdings in response to a monetary shock. This drawdown of securities, however, is to access core deposits and to avoid an external finance premium, rather than to obtain cash to fund loans (as in Kashyap and Stein, 2000). ${ }^{29}$

Loan-to-core deposit ratios are highly and negatively correlated with securities-toasset ratios (the balance sheet measure used by Kashyap and Stein, 2000). As shown in table 3, a low loan-to-core deposit ratio is associated with a high securities-to-asset ratio for almost all banks (the ratios are negatively correlated with one another); the only

\footnotetext{
${ }^{29}$ Many securities are classified by banks as "available-for-sale" and are measured at fair value. Monetary policy changes can potentially influence these fair values and this consideration may be important when analyzing the relationship between lending growth and securities holdings. Moreover, some banks may hold a high proportion of their assets in securities because they need such collateral for their payment operations or other business activities. Thus, changes in securities-to-assets ratios can be difficult to interpret.
} 
exception are those banks with very high loan-to-core deposit ratios (greater than 1.1) and little relationship lending (low relationship lenders).

Smaller banks are often high relationship lenders, but there are many small banks that are not (figure 4). Indeed, some small banks specialize in only holding very large C\&I loans. Thus, we would argue that our measure of relationship lenders is more accurate than bank size. Overall, the Kashyap and Stein approach reflects many aspects of our view of banking, but we would argue that the management of core deposits and its complementarity to relationship lending is the key element that makes banks special.

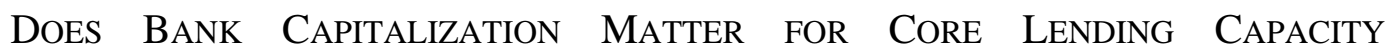
CONSTRAINED BANKs? Several authors have found that banks with low regulatory capital are most affected by monetary contractions, but not expansions (Kishan and Opiela, 2000; Kishan and Opiela, 2006). This result also seems to hold for Europe (Altunbas, Fazylov and Molyneux, 2002, Gambacorta, 2005). Moreover, a bank’s capitalization seems to significantly influence the pricing of individual loans, suggesting that some bank dependent borrowers face significant costs in switching lenders (Hubbard, Kutter and Palia, 2002). Bank capitalization fits easily into our analysis, as banks with low capitalization would face an even higher external finance premium if they had to shift from core deposits to nondeposit liabilities. Thus, banks with a loan-to-core deposit ratio of around one would be most affected by a relatively low level of capital-to-assets.

We expanded our analysis by stratifying the high relationship lenders by their capitalization. As shown in table 4, only lower capital, high relationship banks (those banks that have capital-to-asset ratios in the bottom quartile and have high proportions of loans originated in amounts below $\$ 1$ million) exhibit significant evidence of a bank lending channel. ${ }^{30}$

Is There A Significant BAnK Lending Channel Effect for Mortgages? Most mortgages, unlike most C\&I loans, are now commoditized loans. The demands of the secondary markets have made the pricing and product offerings in the mortgage

\footnotetext{
${ }^{30}$ Cut-offs for bank capitalization quartiles were computed on a quarter-by-quarter basis.
} 
market fairly standardized. Thus, we would expect most mortgages to involve little in the way of relationship lending and, indeed, mortgage brokers and bankers - who have little capacity to deal with relationship borrowers-are ubiquitous.

Our model suggests that loan-to-core deposit ratios would be unimportant in determining the mortgage rates offered by banks and that mortgage rates would generally move one-for-one with market rates. When we repeat our analysis for mortgage loans rather than C\&I loans, we find that no relationship lender group (high, medium or low) shows evidence of a significant bank lending channel for mortgage loans, regardless of the range for the ratio of loans-to-core deposits (see table 5). ${ }^{31}$ Therefore, the mortgage lending response to monetary policy changes appear consistent with the predictions of the model.

Does the Herfindahl for a BanK’s Deposit Market Matter for a BanK’s RESPONSE TO MONETARY POLICY? Some authors have argued that a bank that operates in a market with high deposit concentrations might be more immune to deposit rate fluctuations. However, our model actually suggests a different interaction. We expect the effect of monetary policy on bank lending to be bigger as the deposit-weighted HHI increases because the gap between the costs associated with deposits (which are supposedly lower in a more concentrated market) and the costs associated with marketpriced nondeposit liabilities is larger. Thus, the jump in the external premium would be all the greater when a bank has market power in its deposit market. This bigger jump suggests that banks with loan-to-core deposit ratios near one would contract their lending more in response to higher interest rates, all other things equal. Regardless of which theory might hold, when we examined the interaction of HHIs for banks with interest rates and loan-to-core deposit ratios in our empirical model, we found no significant additional effects to the results described earlier in our paper. ${ }^{32}$

\footnotetext{
${ }^{31}$ Our relationship groups are still created using the ratio of small C\&I loans to total C\&I loans because we do not have any readily available measure of relationship lending for mortgage loans. However, for this analysis only, we screened out any bank that has a mortgage loan-to-asset ratio of less than five percent.

${ }^{32}$ We estimated the following specification:
} 


\section{CONCLUSION}

Much of the discussion of the "bank lending channel" has focused on whether monetary policy can significantly affect the relative pricing of bank loans by reducing banks' access to loanable funds. Although the data on interest rate spreads (for banks' cost of funds and for the prime loans offered by banks) are consistent with the bank lending channel mechanism, such data are also consistent with a tightening of monetary policy that worsens both borrowers' and banks' balance sheets. Such balance sheet effects alone could conceivably explain why it is observed that borrowing becomes more expensive (i.e., there are higher spreads) during periods of tighter monetary policy. Thus, the identification of a "pure" bank lending channel where the contraction of loans reflects rising funding costs for banks, and not borrower balance sheet deterioration, has been difficult.

In theory, we show that the only banks that are likely to raise loan rates substantially in response to an increase in the federal funds rate are banks with a high proportion of relationship borrowers who are close to a loan-to-core deposit ratio of one. These banks must substitute higher-cost nondeposit liabilities, which have an external finance premium, for core deposits, which do not because of deposit insurance. They also face higher marginal costs as loan-to-core deposit ratios approach one because of the additional costs associated with lending to default-prone relationship borrowers.

All other banks fall into one of two groups. First, one group of banks (consisting of about 30 percent of all U.S. banks) provides relationship loans (where they have loan origination and monitoring advantages relative to capital markets) with core deposit funding (where they can pass along the benefit of a sticky price on deposits). These "traditional banks" tend to lend out less than the deposits they take in, so they have a “buffer stock” of core deposits. This buffer stock of core deposits can be used to mitigate

$$
\begin{aligned}
& \Delta \log \left(L_{k i}\right)=\sum_{j=1}^{4} \alpha_{j} \Delta \log \left(L_{t, t-j}\right)+\sum_{j=0}^{4} \mu_{j} \Delta R_{t-j}+\sum_{j=0}^{4} \pi_{j} \Delta G D P_{t-j}+\Theta T I M E_{t}+\sum_{k=1}^{3} \rho_{k} \text { QUARTER }+\sum_{k=1}^{n} \Psi_{k} F R B_{k i}+ \\
& C_{i, t-1}\left\{\eta+\delta T I M E_{i}+\sum_{j=0}^{4} \phi_{j} \Delta R_{t-1}+\sum_{j=0}^{4} \gamma_{j} \Delta G D P_{t-1}\right\}+C_{t, t-1} H H I_{t, t}\left\{\vartheta+\theta T I M E_{t}+\sum_{j=0}^{4} \xi_{j} \Delta R_{t-j}+\sum_{j=0}^{4} \varsigma_{j} \Delta G D P_{t-1}\right\}+\varepsilon_{i t}
\end{aligned}
$$

Qualitatively, the empirical results were similar regardless of whether we used an average HHI, or a deposit-weighted HHI, for each entity. Therefore, institutional differences across institutions in the booking of deposits at the head office did not materially influence our findings. 
the full effect of tighter monetary policy on their bank-dependent borrowers. In this manner, the business strategy of "traditional banks" acts as a "core deposit mitigation channel" to provide funds to bank-dependent borrowers when there are monetary shocks. In effect, there is no bank lending channel of monetary policy associated with these traditional banks.

Second, another group of banks (also consisting of about 30 percent of all U.S. banks) mainly relies on managed liabilities that are priced at market rates. These banks do not have to shift from insured deposits to managed liabilities in response to tighter monetary policy because their loans are already funded with managed liabilities. For these banks as well, there is no unique bank lending channel of monetary policy.

Our empirical evidence is consistent with this stratification. We find evidence of a bank lending channel for monetary policy only for banks that specialize in relationship lending and also have a loan-to-deposit ratio near one - these banks significantly reduce lending in response to a monetary contraction. For the other groups of banks, there is no evidence of a bank lending channel.

Moreover, statistical importance is not economic importance. Although the banks that reduce lending significantly in response to a monetary contraction account for almost 40 percent of U.S. banks, they hold only about six percent of U.S. banking assets. Moreover, among these banks, only the ones with relatively low capital-to-asset ratios seem to account for the bulk of the lending reduction. Thus, in the United States, the bank lending channel seems limited in scope and importance, mainly because few banks switch from core deposits to managed liabilities in response to changes in interest rates. 


\section{Figure 1}

\section{Core Lending Capacity and Its Effect on Loan Rates}

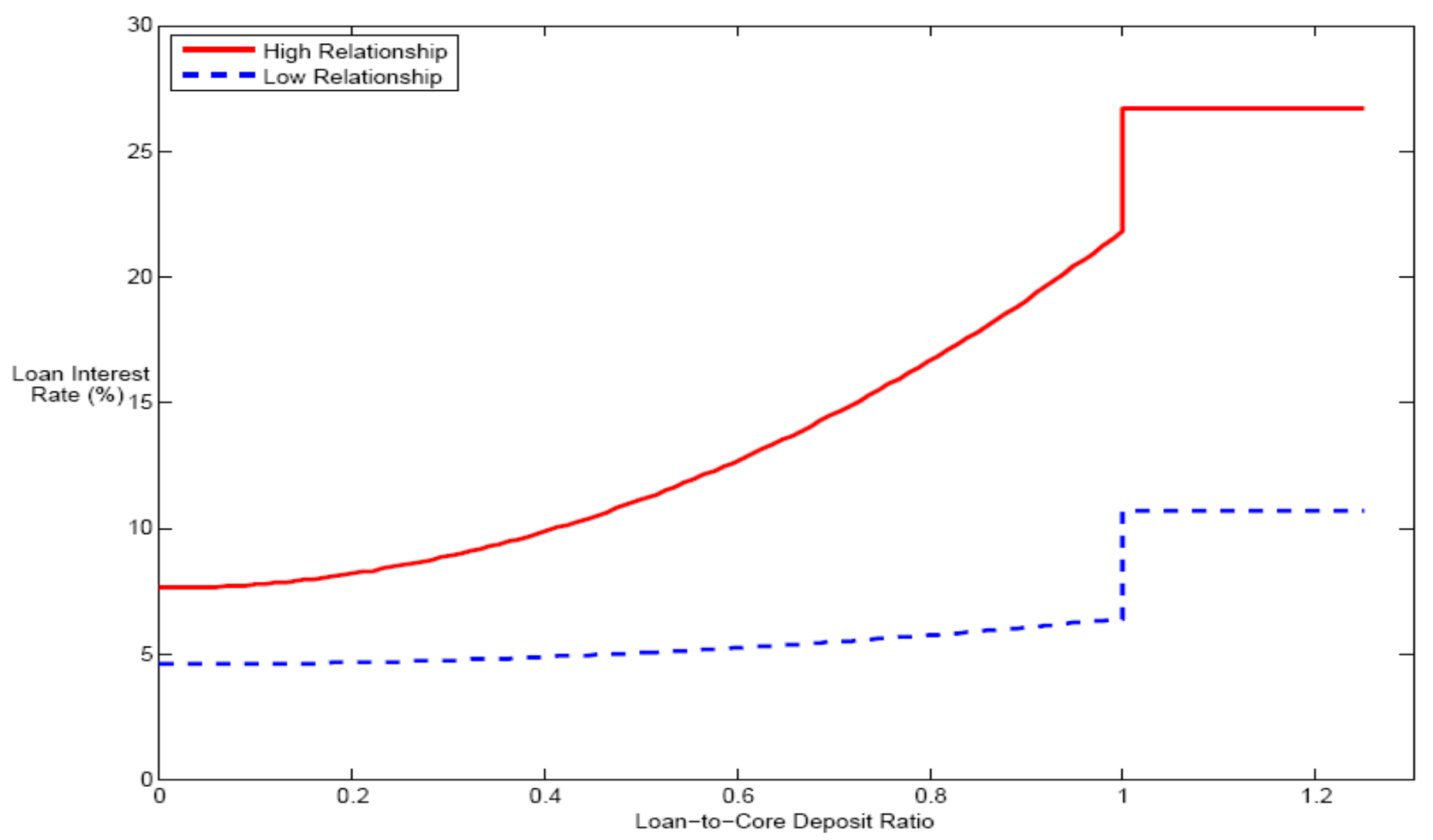

* Assumptions based on the theory developed below using a lognormal distribution of returns for the borrowers: For the high relationship lenders with a loan-tocore deposits ratio less than 100 percent, $\rho=0.075, \delta=0.80, \phi=0.00, \sigma=2.25, \mu=2.25$. For the high relationship lenders with a loan-to-core deposits ratio greater than 100 percent, the same parameters hold, except $\phi=0.15$. For low relationship lenders with a loan-to-core deposits ratio less than 100 percent, $\rho=$ $0.010, \delta=0.95, \phi=0.00, \sigma=2.25, \mu=2.25$. For low relationship lenders with a loan-to-core deposits ratio greater than 100 percent, the same parameters hold, except that $\phi=0.05$. For both low and high relationship lenders, loan demand is assumed to be linear $\left(L^{\mathrm{D}}=\mathrm{c}-\beta^{*} \mathrm{r}_{\mathrm{L}}\right)$. However, equilibrium loan rates can also be derived (as well as similar charts) for $L^{\mathrm{D}}=\left(\alpha^{*} q-\mathrm{r}_{\mathrm{L}}\right) / \beta$, which is a non-linear demand function that is dependent on the payoff and probability of success of the firm's project. 


\section{Figure 2}

\section{Effect of Core Lending Capacity on the Spread}

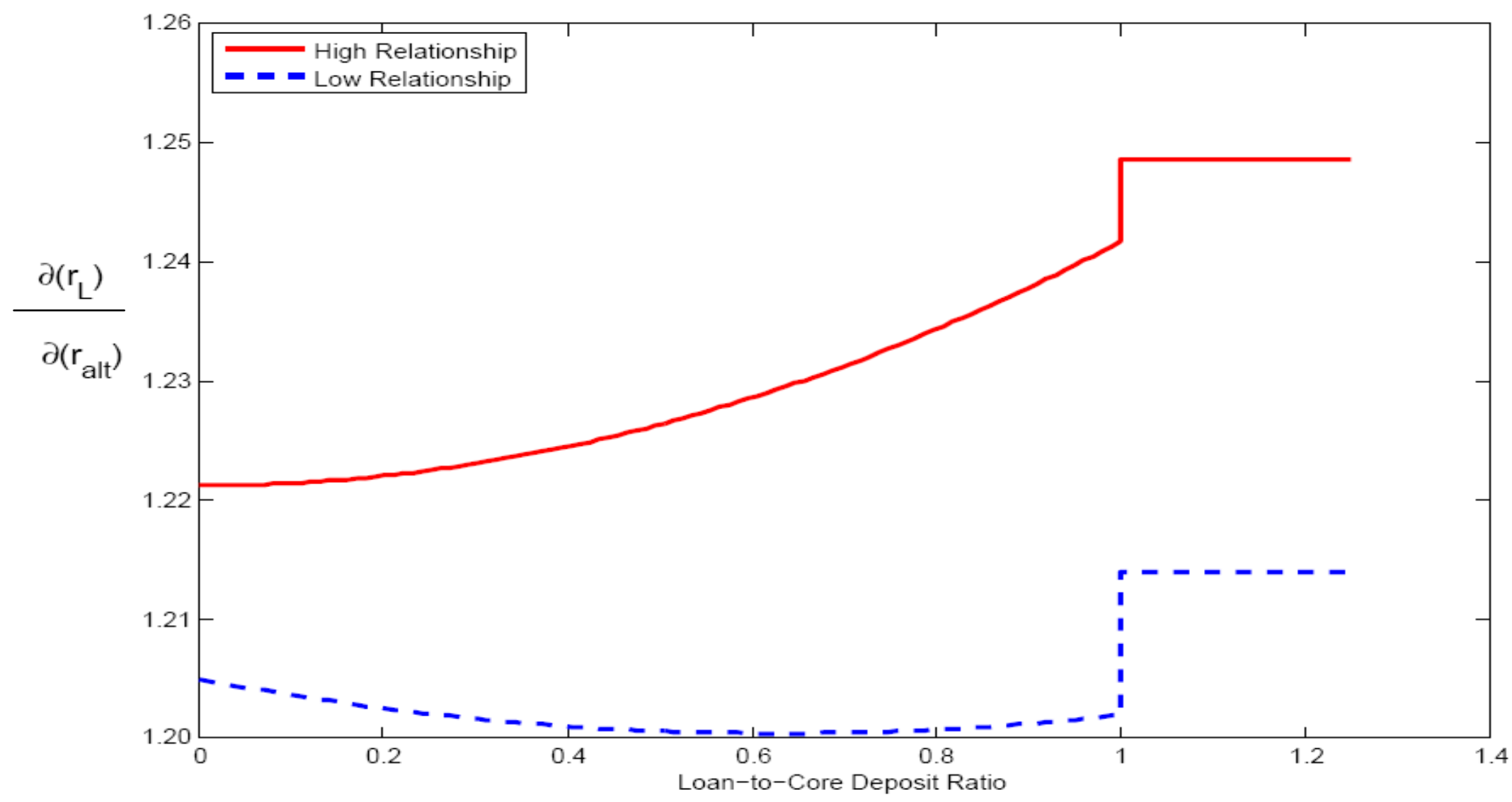

* Assumptions based on the theory developed below using a lognormal distribution of returns for the borrowers: For the high relationship lenders with a loan-tocore deposits ratio less than 100 percent, $\rho=0.075, \delta=0.80, \phi=0.00, \sigma=2.25, \mu=2.25$. For the high relationship lenders with a loan-to-core deposits ratio greater than 100 percent, the same parameters hold, except $\phi=0.15$. For low relationship lenders with a loan-to-core deposits ratio less than 100 percent, $\rho=$ $0.010, \delta=0.95, \phi=0.00, \sigma=2.25, \mu=2.25$. For low relationship lenders with a loan-to-core deposits ratio greater than 100 percent, the same parameters hold, except that $\phi=0.05$. For high relationship lenders, $\beta=-0.01$, and for low relationship lenders $\beta=-2.00$. For both low and high relationship lenders, loan demand is assumed to be linear $\left(L^{\mathrm{D}}=\mathrm{c}-\beta^{*} \mathrm{r}_{\mathrm{L}}\right)$. However, equilibrium loan rates can also be derived (as well as similar charts) for $L^{\mathrm{D}}=\left(\alpha^{*} q-\mathrm{r}_{\mathrm{L}}\right) / \beta$, which is a non-linear demand function that is dependent on the payoff and probability of success of the firm's project. 
Figure 3

Relationship Lending Intensity Score Cut-offs

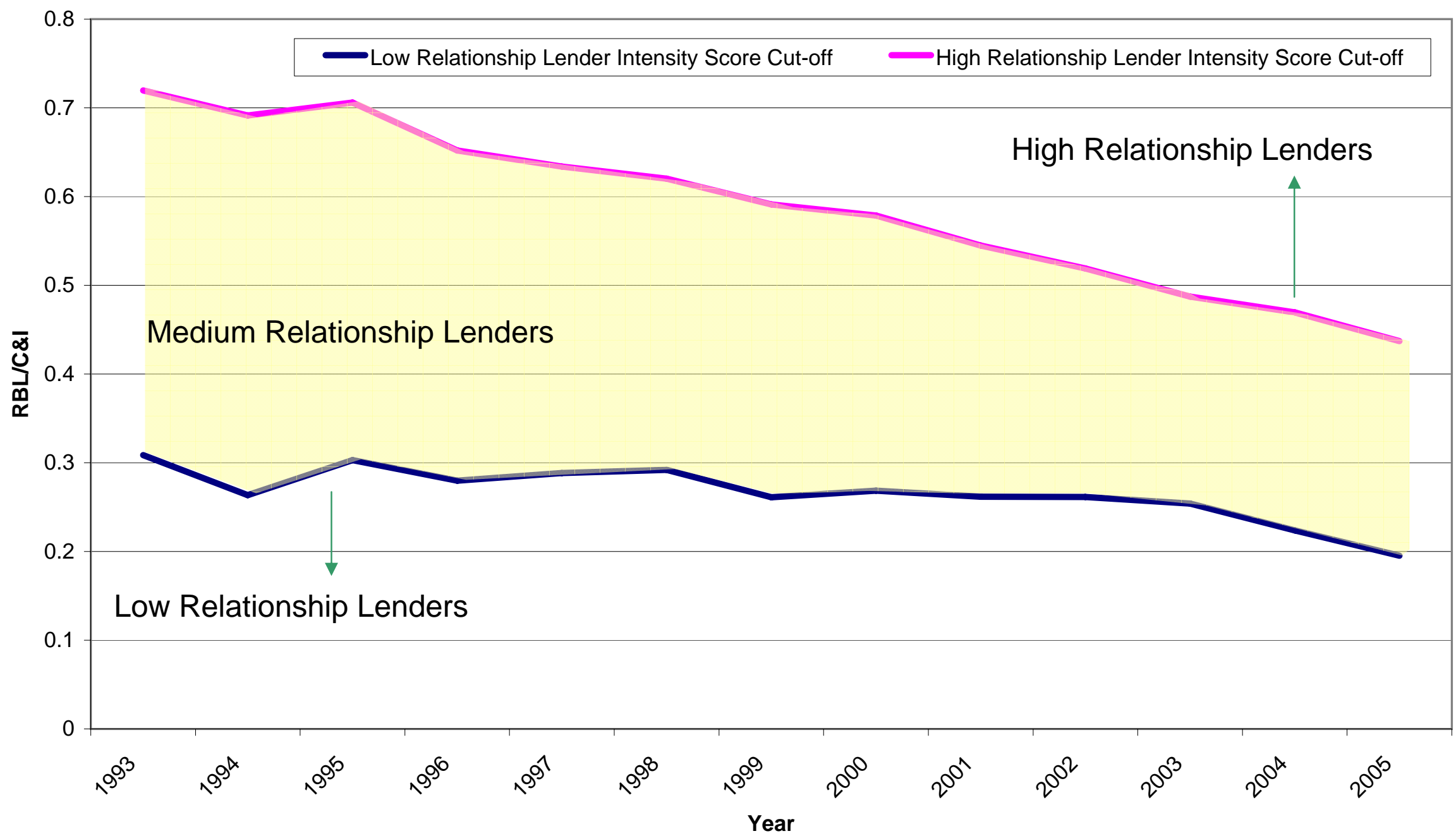

In each year (2nd quarter), the high relationship lender intensity score cut-off is the 5th percentile of the RBL/C\&I distribution and the low relationship lender intensity score cut-off is the 1st percentile of the RBL/C\&I distribution. 
Figure 4

Box Plots of Total Assets for Top Holders Stratified by Relationship Lender Status

( $\mathrm{H}=$ High, M=Medium, L=Low)

(1993:Q2 - 2005:Q2)

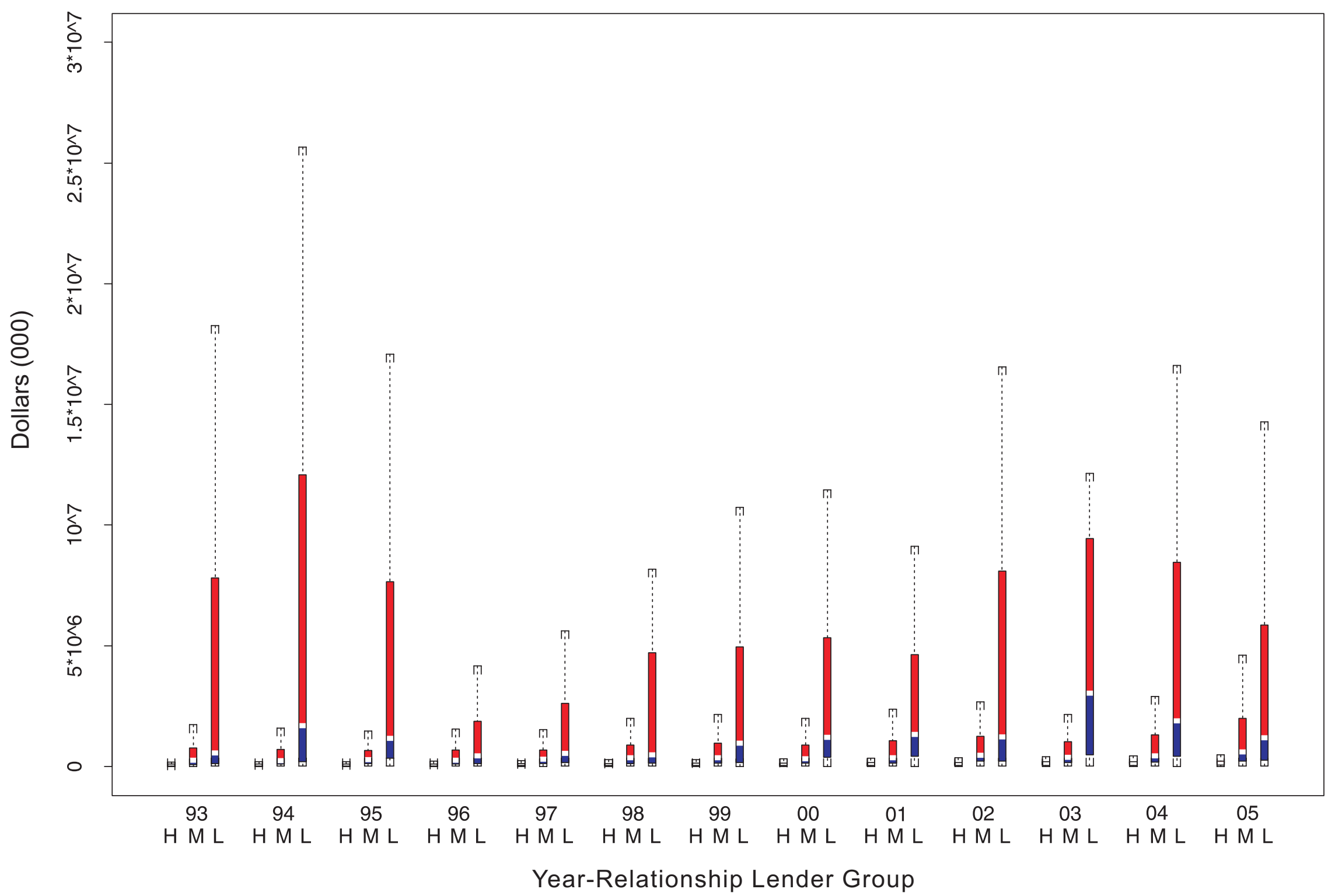


Figure 5

Loan-to-Core Deposit Ratios by Relationship Lender Group
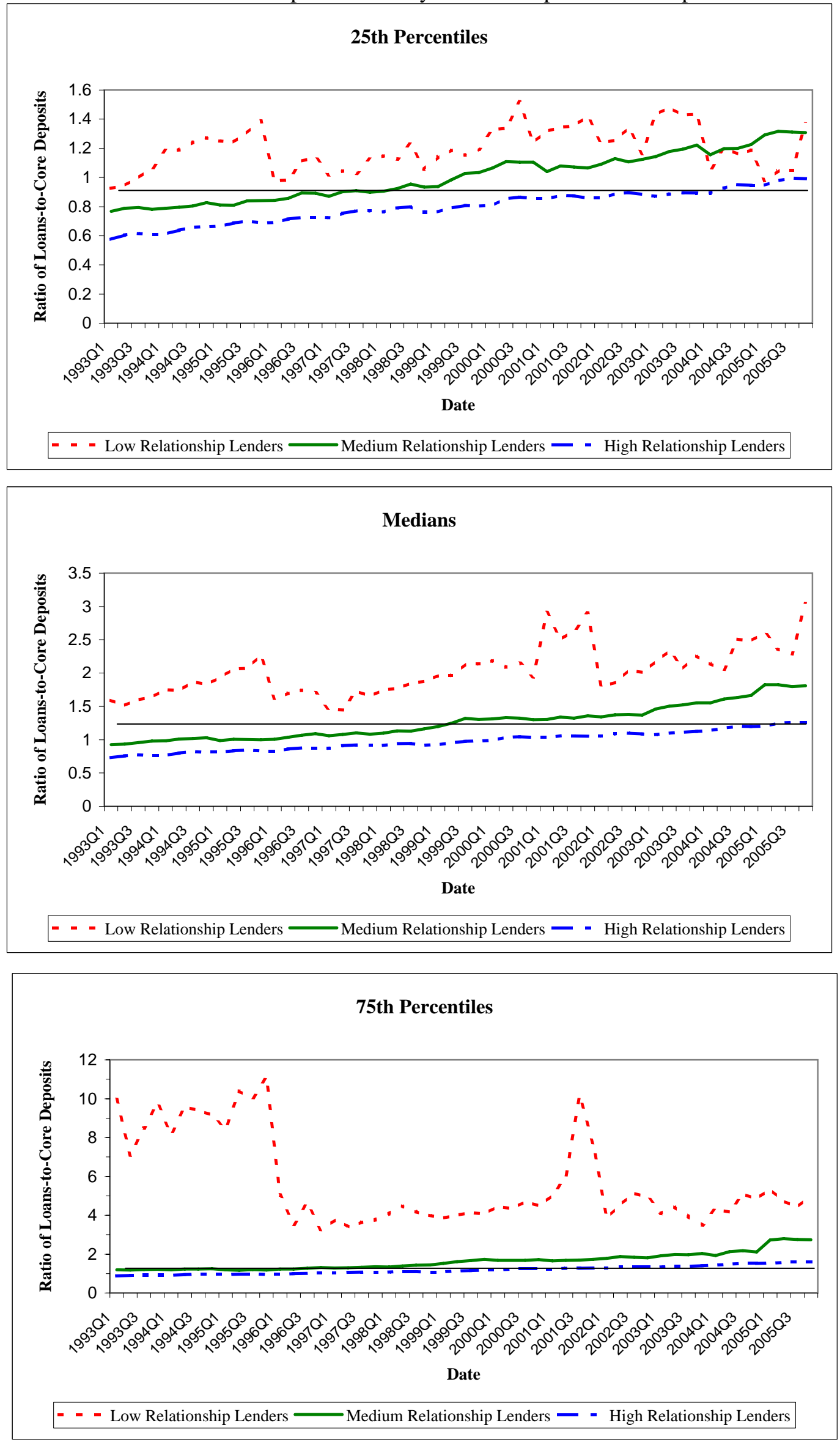
Table 1

How Many Banks Are Core Lending Capacity Constrained?

Proportion of Banks by Relationship Lender Status and by Range for the Loan-to-Core Deposit Ratio*

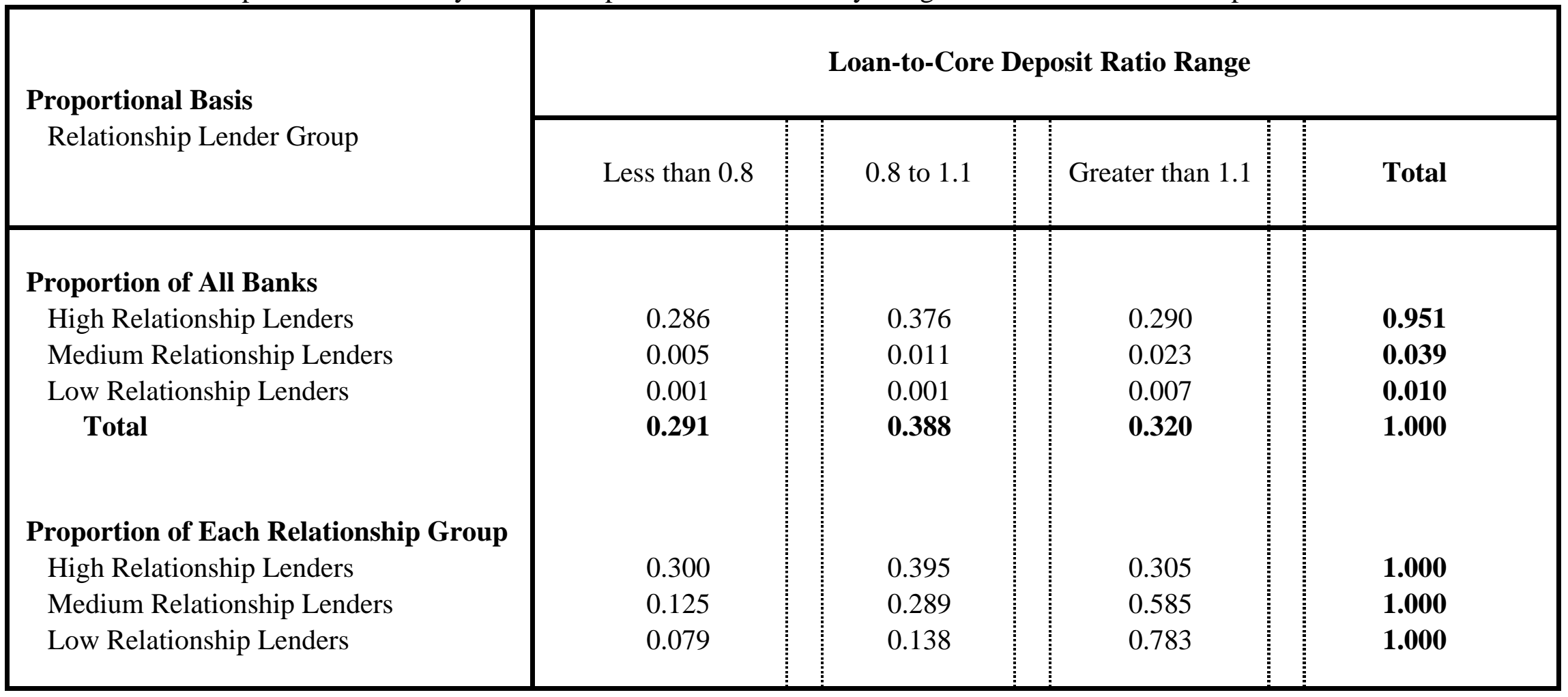

* Proportions are calculated on a bank-quarter basis. 
Table 2

Partial Derivatives of Bank C\&I Lending Growth*

with Respect to the Monetary Policy Indicator (R) and Core Lending Capacity (C) (P-Values in parentheses)

\begin{tabular}{|c|c|c|c|}
\hline \multirow{2}{*}{ Relationship Lender Group } & \multicolumn{3}{|c|}{ Loan-to-Core Deposit Ratio Range } \\
\hline & Less than 0.8 & 0.8 to 1.1 & Greater than 1.1 \\
\hline High Relationship Lenders & $\begin{array}{c}0.014 \\
(0.399)\end{array}$ & $\begin{array}{c}-0.050 \\
(0.005)\end{array}$ & $\begin{array}{r}-0.0002 \\
(0.711)\end{array}$ \\
\hline Medium Relationship Lenders & $\begin{array}{c}0.066 \\
(0.639)\end{array}$ & $\begin{array}{c}0.025 \\
(0.837)\end{array}$ & $\begin{array}{c}-0.0009 \\
(0.687)\end{array}$ \\
\hline Low Relationship Lenders & $\begin{array}{c}-0.343 \\
(0.136)\end{array}$ & $\begin{array}{c}0.450 \\
(0.119)\end{array}$ & $\begin{array}{l}0.0001 \\
(0.091)\end{array}$ \\
\hline Difference (High minus Low) & $\begin{array}{c}0.356 \\
(0.083)\end{array}$ & $\begin{array}{l}-0.500 \\
(0.065)\end{array}$ & $\begin{array}{c}-0.0003 \\
(0.580)\end{array}$ \\
\hline
\end{tabular}

* Partial derivatives are evaluated at the sample means of the data. 
Table 3

The Relationship between Loan-to-Core Deposit Ratios and Securities-to-Assets Ratios Pearson Correlation Coefficients (P-Values in parentheses)

\begin{tabular}{|c|c|c|c|}
\hline \multirow{2}{*}{ Relationship Lender Group } & \multicolumn{3}{|c|}{ Loan-to-Core Deposit Ratio Range } \\
\hline & Less than 0.8 & 0.8 to 1.1 & Greater than 1.1 \\
\hline High Relationship Lenders & $\begin{array}{c}-0.746 \\
(<0.001)\end{array}$ & $\begin{array}{c}-0.352 \\
(<0.001)\end{array}$ & $\begin{array}{c}-0.018 \\
(<0.001)\end{array}$ \\
\hline Medium Relationship Lenders & $\begin{array}{c}-0.731 \\
(<0.001)\end{array}$ & $\begin{array}{c}-0.268 \\
(<0.001)\end{array}$ & $\begin{array}{c}0.061 \\
(<0.001)\end{array}$ \\
\hline Low Relationship Lenders & $\begin{array}{c}-0.842 \\
(<0.001)\end{array}$ & $\begin{array}{l}-0.125 \\
(0.017)\end{array}$ & $\begin{array}{c}-0.012 \\
(0.594)\end{array}$ \\
\hline
\end{tabular}




\section{Table 4}

Does Bank Capitalization Matter for Core Lending Capacity Constrained Banks?

\section{Partial Derivatives of Bank C\&I Lending Growth*}

with Respect to the Monetary Policy Indicator (R) and Core Lending Capacity (C )

\begin{tabular}{|c|c|c|}
\hline \multirow{2}{*}{$\begin{array}{c}\text { Relationship Lender Group } \\
\text { Loan-to-Core Deposit Ratio Range }\end{array}$} & \multicolumn{2}{|c|}{ Level of Capitalization } \\
\cline { 2 - 3 } & Capital-to-Asset Ratio in the Bottom Quartile & Capital-to-Asset Ratio in the Top Three Quartiles \\
\hline High Relationship Lenders & & \\
$0.80<$ C $<1.1$ & & -0.028 \\
& $\mathbf{- 0 . 1 1 5}$ & $(0.189)$ \\
\hline
\end{tabular}

* Partial derivatives are evaluated at the sample means of the data. 
Table 5

Partial Derivatives of Bank Mortgage Lending Growth*

with Respect to the Monetary Policy Indicator (R) and Core Lending Capacity (C)

(P-Values in parentheses)

\begin{tabular}{|c|c|c|c|}
\hline \multirow{2}{*}{ Relationship Lender Group } & \multicolumn{3}{|c|}{ Loan-to-Core Deposit Ratio Range } \\
\hline & Less than 0.8 & 0.8 to 1.1 & Greater than 1.1 \\
\hline High Relationship Lenders & $\begin{array}{l}-0.010 \\
(0.219)\end{array}$ & $\begin{array}{l}-0.006 \\
(0.548)\end{array}$ & $\begin{array}{c}-0.0006 \\
(0.768)\end{array}$ \\
\hline Medium Relationship Lenders & $\begin{array}{c}-0.003 \\
(0.962)\end{array}$ & $\begin{array}{c}0.053 \\
(0.364)\end{array}$ & $\begin{array}{c}0.002 \\
(0.205)\end{array}$ \\
\hline Low Relationship Lenders & $\begin{array}{c}-0.212 \\
(0.078)\end{array}$ & $\begin{array}{l}-0.213 \\
(0.292)\end{array}$ & $\begin{array}{l}0.0014 \\
(0.420)\end{array}$ \\
\hline Difference (High minus Low) & $\begin{array}{c}0.202 \\
(0.073)\end{array}$ & $\begin{array}{c}0.207 \\
(0.291)\end{array}$ & $\begin{array}{c}-0.0020 \\
(0.447)\end{array}$ \\
\hline
\end{tabular}

* Partial derivatives are evaluated at the sample means of the data. 


\section{REFERENCES}

Adams, R.M. and D.F. Amel, 2005, “The Effects of Local Banking Market Structure on the Bank Lending Channel of Monetary Policy,” Finance and Economics Discussion Series working paper, Federal Reserve Board, 2005-16, April.

Altunbas, Y., O. Fazylov, and P. Molyneux, 2002, "Evidence on the Bank Lending Channel in Europe,” Journal of Banking and Finance, 26, 2093-2110.

Berlin, M. and L.J. Mester, 1999, “Deposits and Relationship Lending,” The Review of Financial Studies, 12, Fall, pp. 579-607.

Bernanke, B.S. and A. Blinder, 1992, “The Federal Funds Rate and the Channels of Monetary Transmission,” American Economic Review, September, 83(4), pp.90221.

Bernanke, B.S. and M. Gertler, 1995, "Inside the Black Box: The Credit Channel of Monetary Policy Transmission," The Journal of Economic Perspectives, 9, Autumn, pp. 27-48.

Bernanke, B.S. and I. Mihov, 1998, “Measuring Monetary Policy,” Quarterly Journal of Economics, August, 113(3), pp.869-902.

Diamond, D.W. and R.G. Rajan, 2006, "Money in a Theory of Banking," American Economic Review, 96, 30-53.

Freixas, X. and J. Jorge, 2007, "The Role of Interbank Markets in Monetary Policy: A Model with Rationing,” working paper, Department of Economics and Business, Universitat Pompeu Fabra, June.

Gambacorta, L., 2005, “Inside the Bank Lending Channel,” European Economic Review, 49, 1737-59.

Gatev, E. and P.E. Strahan, 2005, “Banks’ Advantage in Hedging Liquidity Risk: Theory and Evidence from the Commercial Paper Market,” The Journal of Finance, 61, April, pp. 867-892.

Hannan, T.H. and A.N. Berger, 1991, “The Rigidity of Prices: Evidence from the Banking Industry," The American Economic Review, 81, September, pp. 938945.

Houston, J.F. and C. James, 1998, "Do bank internal capital markets promote lending?” Journal of Banking and Finance, 22, pp. 899-918.

Houston, J.F., C. James, and D. Marcus, 1997, "Capital market frictions and the role of internal capital markets in banking," Journal of Financial Economics, 46, pp. 13564. 
Hubbard, R.G., K.N. Kuttner, and D.N. Palia 2002, “Are There Bank Effects in Borrowers’ Costs of Funds? Evidence from a Matched Sample of Borrowers and Banks," Journal of Business, 75, October, pp. 559-581.

Jayaratne, J. and D.P. Morgan, 2000, "Capital Market Frictions and Deposit Constraints at Banks,” Journal of Money, Credit, and Banking, 32, pp. 74-92.

Kahn, C., G. Pennacchi, and B. Sopranzetti, 1999, "Bank Deposit Rate Clustering: Theory and Empirical Evidence, The Journal of Finance, 54, December, pp. 2185-2214.

Kashyap, A.K., R.G. Rajan, and J.C. Stein, 2002, "Banks as Liquidity Providers: An Explanation for the Coexistence of Lending and Deposit-taking," The Journal of Finance, 57, February, pp. 33-73.

Kashyap, A.K. and J.C. Stein, 1995, “The Impact of Monetary Policy on Bank Balance Sheets,” Carnegie-Rochester Conference Series on Public Policy, June, pp. 151195.

Kashyap, A.K. and J.C. Stein, 2000, "What Do a Million Observations on Banks Say about the Transmission of Monetary Policy?” The American Economic Review, 90, June, pp. 407-428.

Kishan, R., and T. Opiela, 2000, "Bank size, bank capital, and the bank lending channel," Journal of Money, Credit, and Banking, 32, pp. 121-41.

Kishan, R., and T. Opiela, 2006, "Bank Capital and Loan Asymmetry in the Transmission of Monetary Policy,” Journal of Banking and Finance, 30, pp. 259-85.

Neumark, D. and S.A. Sharpe, 1992, "Market Structure and the Nature of Price Rigidity: Evidence from the Market for Consumer Deposits,” The Quarterly Journal of Economics, 107, May, pp. 657-680.

Peek, J. and D. Holod, 2006, "The Value of Banks of Small Business Lending," Working paper, University of Kentucky, September.

Petersen, M.A. and R.G. Rajan, 1995, "The Effect of Credit Market Competition on Lending Relationships,” Quarterly Journal of Economics, 110, May, pp. 407-443.

Romer, C.D. and D. Romer, 2004, “A New Measure of Monetary Policy Shocks: Deivation and Implications," American Economic Review, 94(4), September, pp.1055-1084.

Van den Heuvel, S.K., 2007, “The Bank Capital Channel of Monetary Policy,” working paper, The Wharton School, University of Pennsylvania, June. 